\title{
Guidance for Mitigating Environmental Concerns During Range Siting
}

\section{US Army Corps of Engineers $\mathrm{B}_{\circledast}$} Engineer Research and Development Center

Ryan Busby, Manroop Chawla, Mike Denight, Dick Gebhart,

Heidi Howard, Tony Palazzo, and Niels Svendsen 
ERDC TR-06-16

December 2006

\section{Guidance for Mitigating Environmental Concerns During Range Siting}

Ryan Busby, Manroop Chawla, Mike Denight, Dick Gebhart, Heidi Howard, Niels Svendsen Construction Engineering Research Laboratory

U.S. Army Engineer Research and Development Center 2902 Newmark Dr

Champaign, IL 61822-1078

Tony Palazzo

Cold Regions Research and Engineering Laboratory

72 Lyme Road

Hanover, NH 13755-1290

Final report

Approved for public release; distribution is unlimited.

Prepared for U.S. Army Corps of Engineers

Under Work Unit 33143 


\begin{abstract}
The effective training of soldiers, leaders, and units is vital to ensure the readiness of the U.S. Army to fight and win decisively in combat. Training must provide the opportunity to practice individual and battle-focused tasks and missions in a setting where conditions are realistic and challenging. To facilitate this, the Army developed and continues to improve its training infrastructure, including combined arms training centers and an array of training areas, ranges, and target systems designed to increase individual skills and unit tactical and technical proficiency in sophisticated weapons systems and equipment.
\end{abstract}

Three key dynamics have evolved in recent years and are adversely affecting the Army's ability to continue to maintain its training mission: (1) a significant growth in environmental regulations to which installations must adhere, (2) many installations are becoming surrounded by population centers and are experiencing closer public scrutiny of activities that occur on installations, (3) transformation of the Army to the Objective Force.

This report provides information encompassing the major environmental factors that influence the planning and siting, design and construction, and operation and maintenance of the range elements most commonly found on training ranges and that possess the highest potential for environmental degradation.

DISCLAIMER: The contents of this report are not to be used for advertising, publication, or promotional purposes. Citation of trade names does not constitute an official endorsement or approval of the use of such commercial products. All product names and trademarks cited are the property of their respective owners. The findings of this report are not to be construed as an official Department of the Army position unless so designated by other authorized documents. 


\section{Contents}

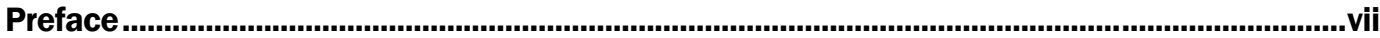

Unit Conversion Factors...................................................................................................................iii

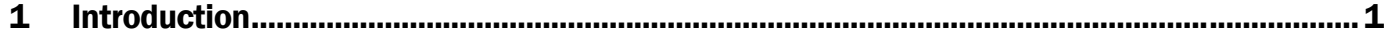

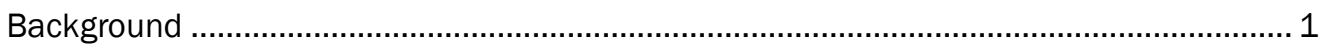

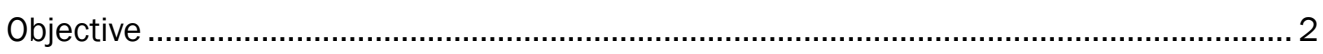

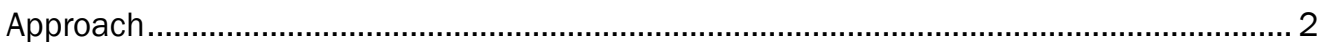

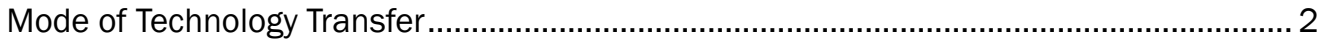

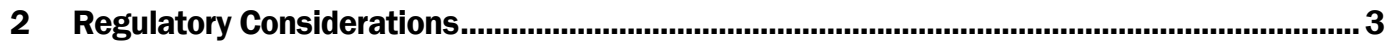

Considerations for NEPA Documents ............................................................................ 3

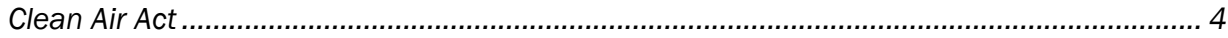

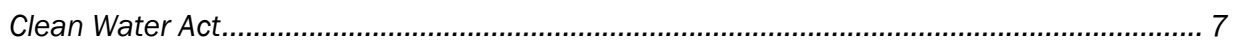

Wetlands Protection Order ………………................................................................ 10

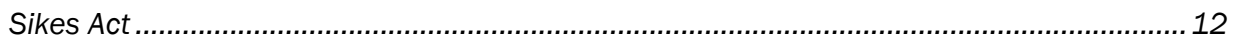

Endangered Species Act......................................................................................... 14

Comprehensive Environmental Response, Compensation, and Liability Act

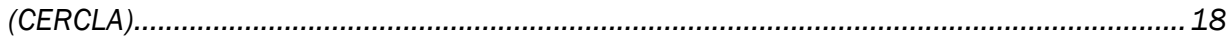

National Historic Preservation Act ............................................................................... 19

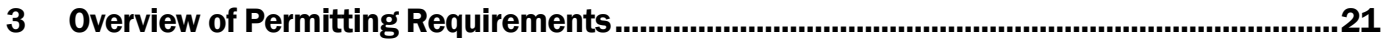

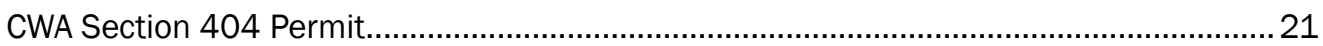

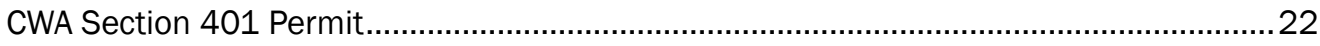

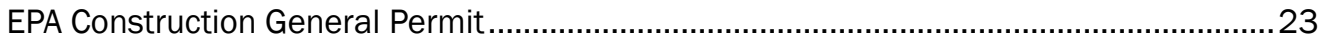

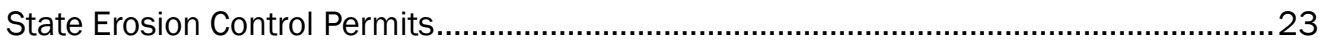

National Historic Preservation Act, Section 106 .........................................................23

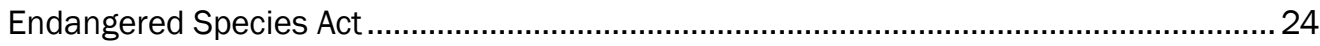

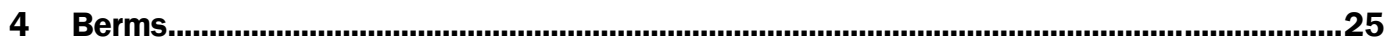

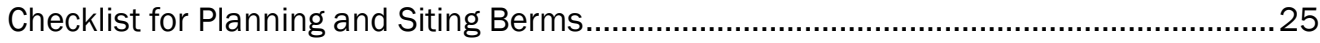

Checklist for Operation and Maintenance of Berms ......................................................... 27

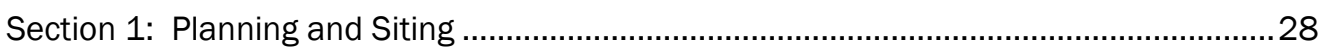

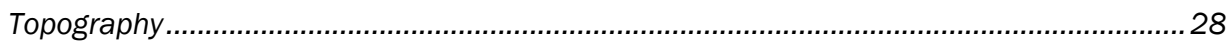

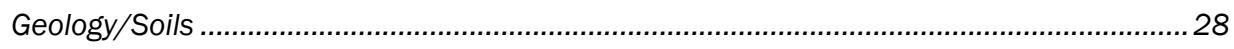

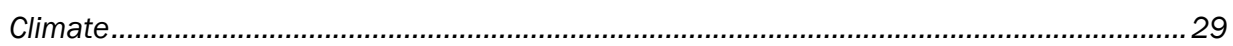

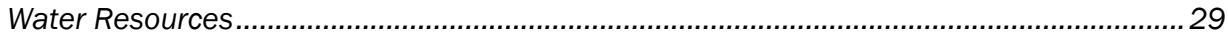

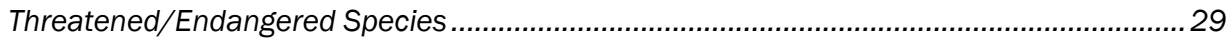

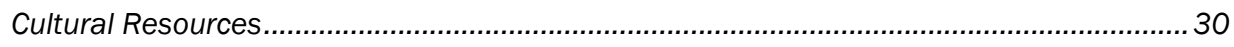

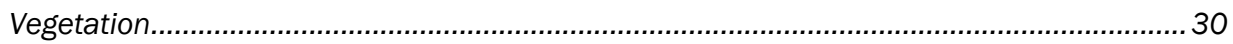

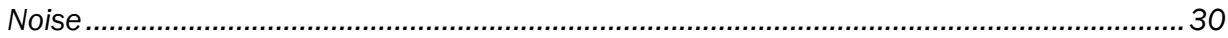

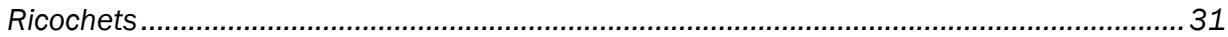


Section 2: Design and Construction......................................................................... 31

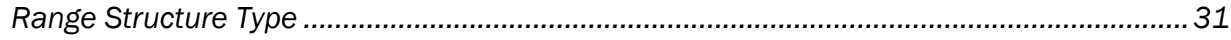

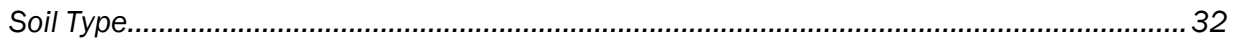

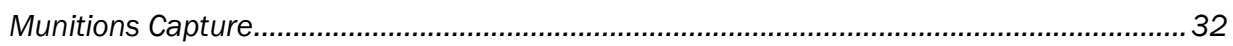

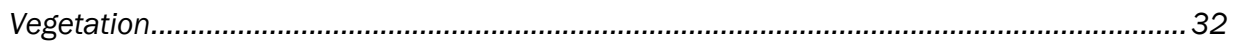

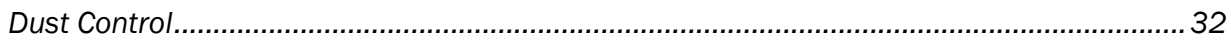

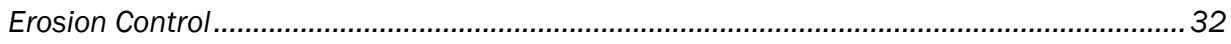

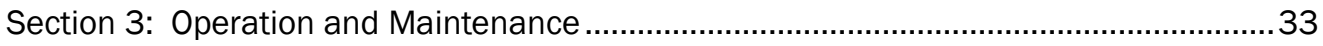

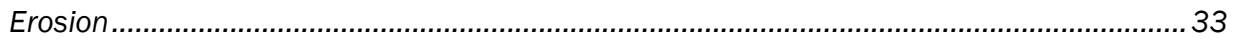

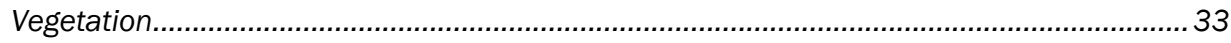

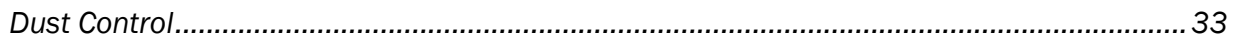

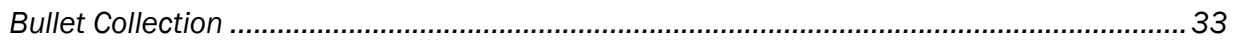

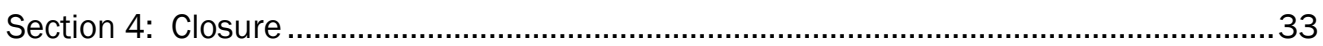

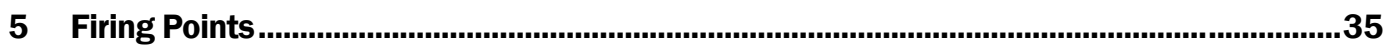

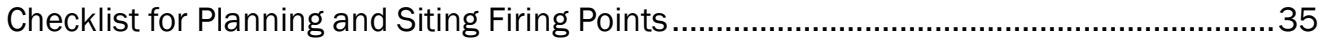

Checklist for Operation and Maintenance of Firing Points ..................................................37

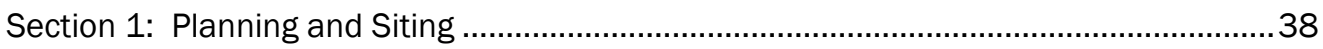

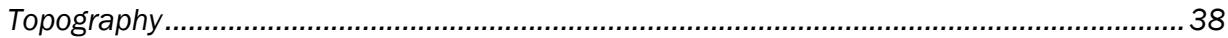

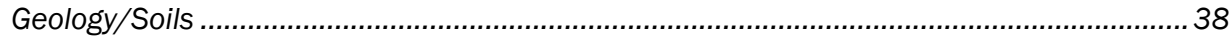

Climate

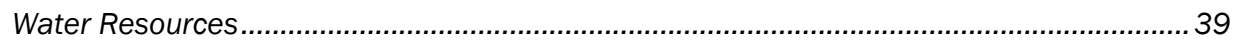

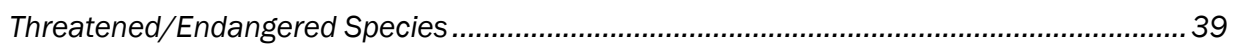

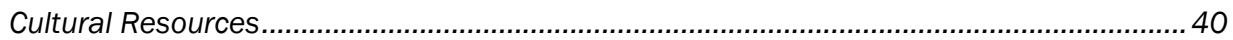

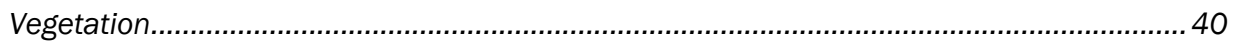

Noise

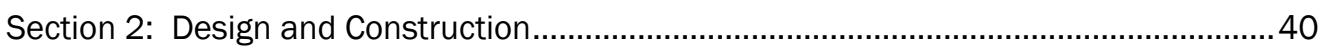

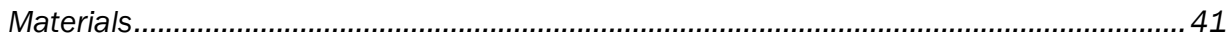

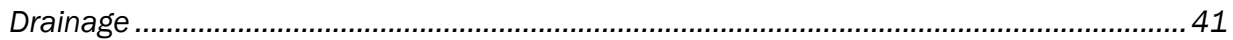

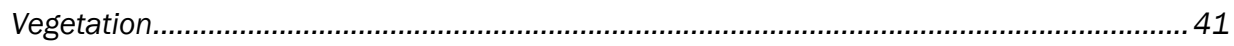

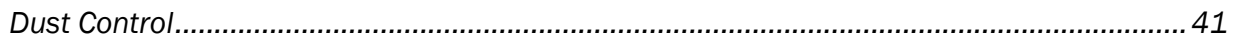

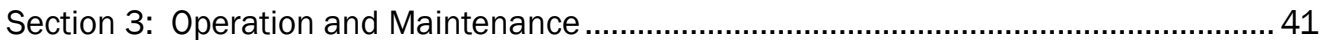

Ruts

Erosion

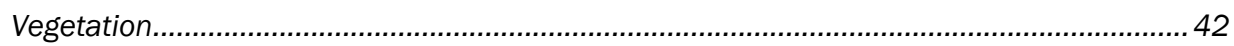

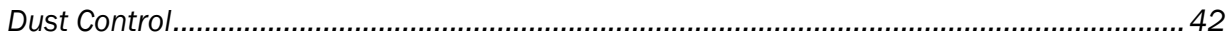

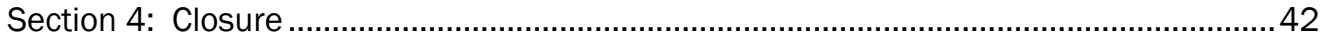

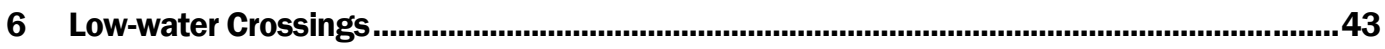

Checklist for Planning and Siting of Low-water Crossings ...............................................43

Checklist for Operation and Maintenance of Low-water Crossings ................................... 45

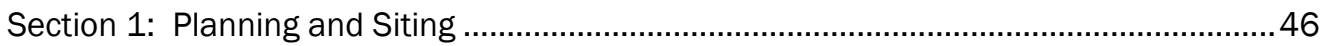

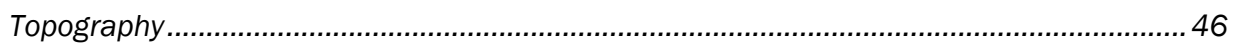

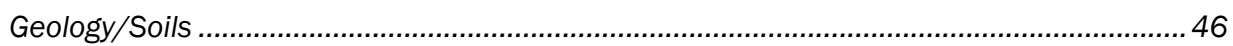

Climate

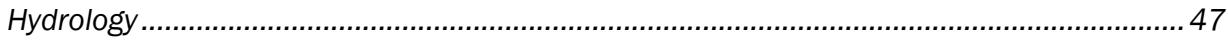




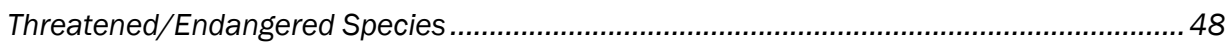

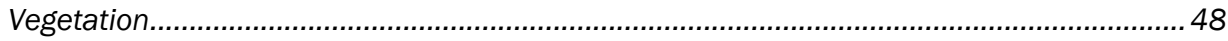

Section 2: Design and Construction...................................................................... 49

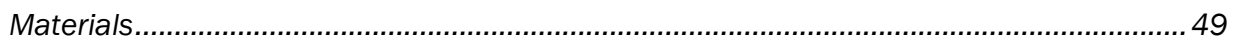

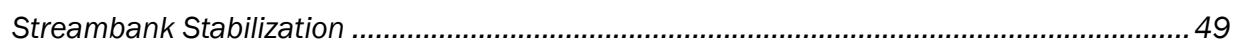

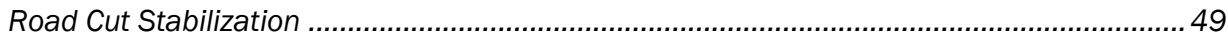

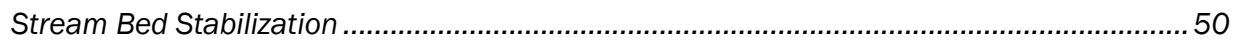

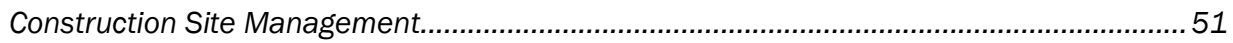

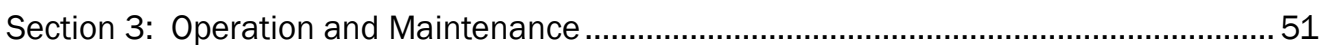

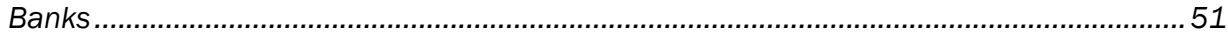

Bed

Section 4: Closure .............................................................................................. 52

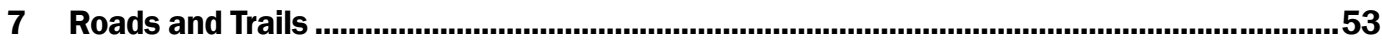

Checklist for Planning and Siting of Roads and Trails.................................................53

Checklist for Operation and Maintenance of Roads and Trails .........................................55

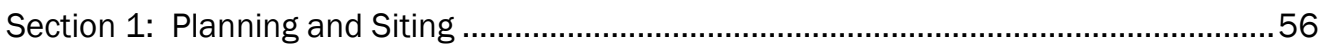

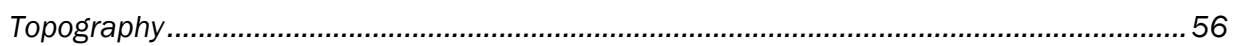

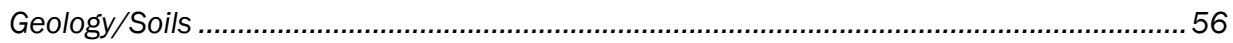

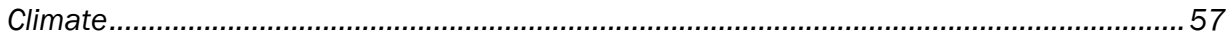

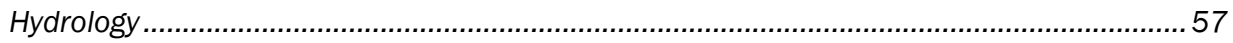

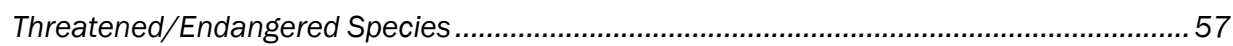

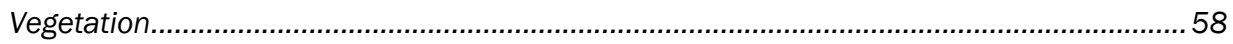

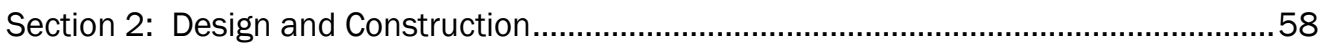

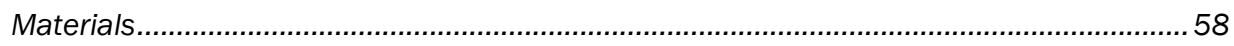

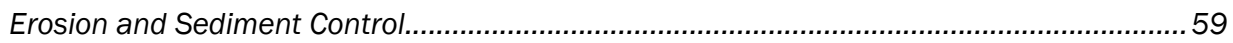

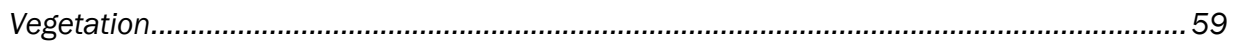

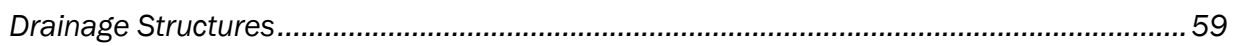

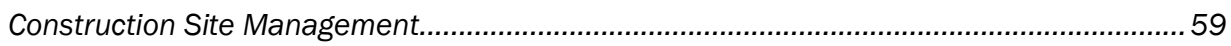

Section 3: Operation and Maintenance ................................................................60

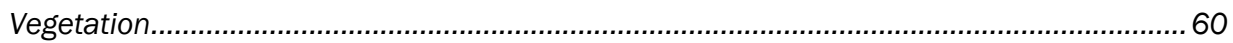

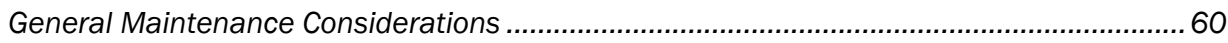

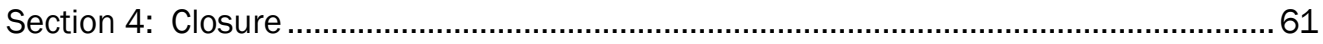

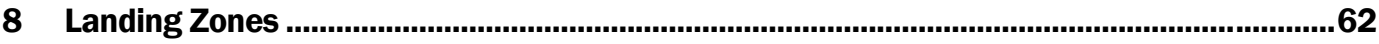

Checklist for Planning and Siting of Landing Zones...................................................6 62

Checklist for Operation and Maintenance of Landing Zones .........................................6. 64

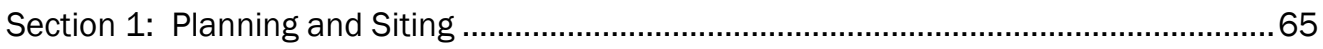

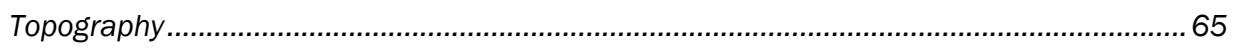

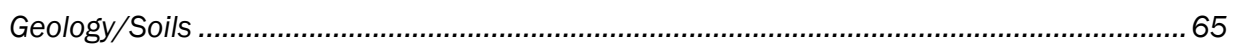

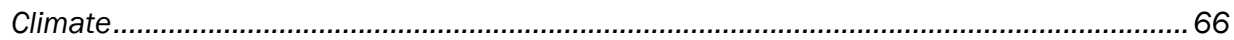

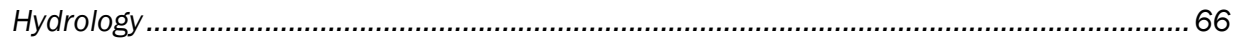

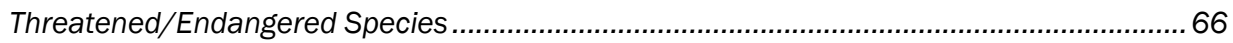

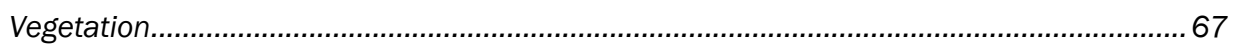

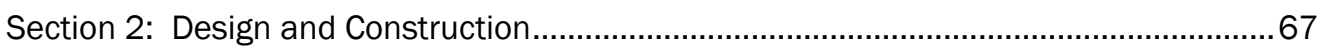

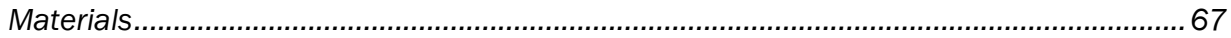




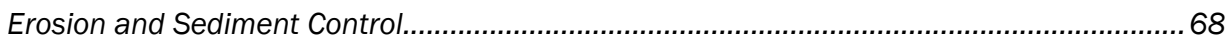

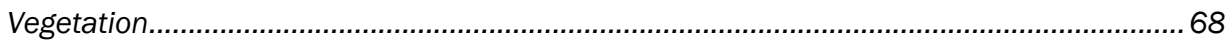

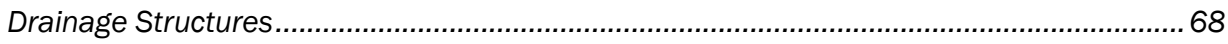

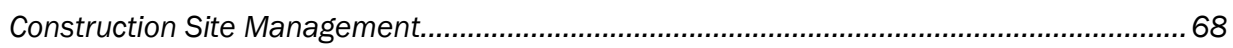

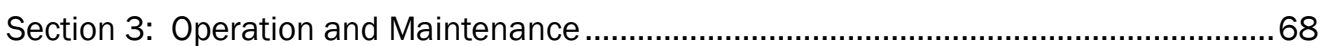

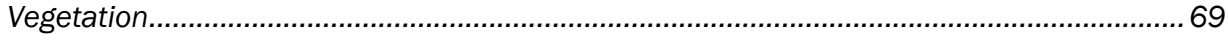

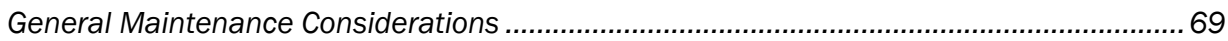

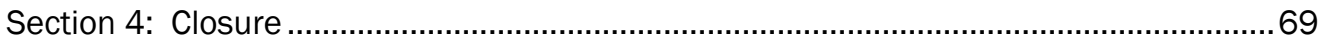

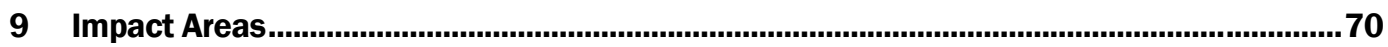

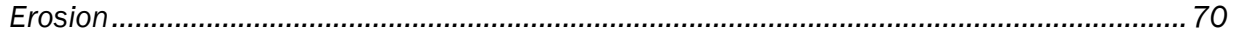

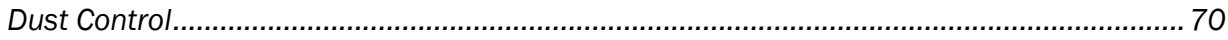

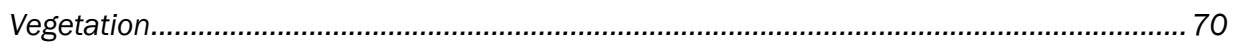

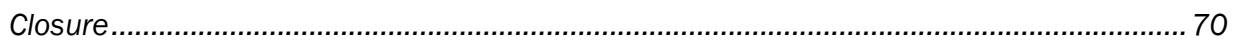

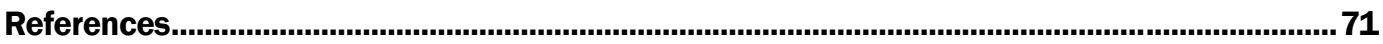

Appendix A: Web Resources for Land Management and Erosion Control Laws and

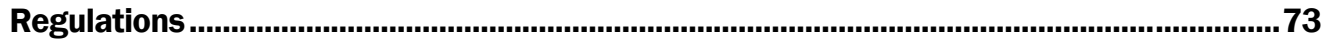

Appendix B: Web Resources for Sustainable Ranges ..........................................................75

Report Documentation Page........................................................................................................8 


\section{Preface}

This report is a deliverable product under military direct-allotted Department of the Army project A896, "Base Facilities Environmental Quality," and is part of a Science and Technology Objective. This work was funded by Headquarters, U.S. Army Corps of Engineers. The Technical Monitor was Scott Belfit.

This report was prepared by Ryan Busby, Manroop Chawla, Mike Denight, Dick Gebhart, and Niels Svendsen, Land and Heritage Conservation Branch (CN-C), and Heidi Howard, Ecological Processes Branch (CN-N), Installations Division (CN), Construction Engineering Research Laboratory (CERL), U.S. Army Engineer Research and Development Center (ERDC), and by Tony Palazzo of the Cold Regions Research and Engineering Laboratory, ERDC. This research was conducted under the general supervision of Dr. Lucy Whalley, Chief CN-C; Dr. J ohn T. Bandy, Chief CN, and Dr. Ilker Adiguzel, Director, CERL.

COL Richard B. J enkins was Commander and Executive Director of ERDC. Dr. J ames R. Houston was Director. 


\section{Unit Conversion Factors}

\begin{tabular}{|l|c|l|}
\hline Multiply & By & To Obtain \\
\hline acres & $4,046.873$ & square meters \\
\hline cubic feet & 0.02831685 & cubic meters \\
\hline cubic inches & $1.6387064 \mathrm{E}-05$ & cubic meters \\
\hline cubic yards & 0.7645549 & cubic meters \\
\hline degrees Fahrenheit & (F-32)/1.8 & degrees Celsius \\
\hline feet & 0.3048 & meters \\
\hline hectares & $1.0 \mathrm{E}+04$ & square meters \\
\hline inches & 0.0254 & meters \\
\hline miles (U.S. statute) & $1,609.347$ & meters \\
\hline pounds (mass) & 0.45359237 & kilograms \\
\hline square feet & 0.09290304 & square meters \\
\hline square inches & $6.4516 \mathrm{E}-04$ & square meters \\
\hline square miles & $2.589998 \mathrm{E}+06$ & square meters \\
\hline square yards & 0.8361274 & square meters \\
\hline yards & 0.9144 & meters \\
\hline
\end{tabular}




\section{Introduction}

\section{Background}

The effective training of soldiers, leaders, and units is vital to ensure the readiness of the U.S. Army to fight and win decisively in combat. To be effective, training must provide soldiers and leaders with the opportunity to practice individual and battle focused tasks and missions in a setting where conditions are realistic and challenging. To facilitate this, the Army developed and continues to improve its training infrastructure, including combined arms training centers and an array of training areas, ranges, and target systems designed to increase individual skills and unit tactical and technical proficiency in sophisticated weapons systems and equipment.

Unfortunately, three key dynamics have evolved in recent years and are adversely affecting the Army's ability to continue to maintain its training mission. The first has been a significant growth in environmental regulations to which installations must adhere. These regulations cover many environmental issues such as threatened and endangered species (Endangered Species Act [ESA] and its amendments ${ }^{1}$ ), water resources (Clean Water Act [CWA] and its amendments), air emissions (Clean Air Act [CAA] and its amendments), and hazardous and toxic wastes (Comprehensive Environmental Response, Compensation, and Liability Act [CERCLA]) and its amendments under the Superfund Amendments and Reauthorization Act (SARA).

http:// www.epa.gov/ superfund/ action/law/ sara.htm The list of environmental requirements is long and characterized by diversity not limited to the above examples. Second, many installations are no longer isolated; they are becoming surrounded by population centers that no longer view the installation and its economic benefit to the community as the major factor in long-term development. As a result, there is closer public scrutiny of activities that occur on installations. The final dynamic is transformation of the Army. This was characterized in past years by modernization with faster, more capable weapons systems and now by transformation to the Objective Force.

\footnotetext{
1 Federal environmental regulations are being amended continually. Appendix A lists the World Wide Web URLs (uniform resource locators) for the laws and regulations cited in this document; the URLs may not be current at the time this report is read.
} 
Range operation and maintenance requirements may constrain the amount of time that ranges can be used for training purposes. These requirements can be exacerbated by design elements that result in environmental compliance problems such as soil erosion, water quality degradation, poor air quality, heavy metals accumulation, and habitat destruction. Standard range designs often do not prevent environmental degradation due to repeated, long-term use experienced by most training ranges.

\section{Objective}

The objective of this report is to provide information encompassing the major environmental factors that influence the planning and siting, design and construction, and operation and maintenance of the range elements most commonly found on training ranges and that possess the highest potential for environmental degradation.

\section{Approach}

A review of standard range designs as they relate to environmental compliance risks was conducted in order to modify existing range design elements to reduce future operation and maintenance requirements while maintaining training realism and improving environmental compliance. Range planning and siting, design and construction, and operation and maintenance modifications are recommended to minimize environmental and public conflicts and constraints in the future, while supporting the ability to train to proficiency.

\section{Mode of Technology Transfer}

This report will be provided to the U.S. Army Engineering and Support Center for inclusion in the RETS [Remote Target System] Range Design Manual, CEHNC-1110-1-23, http://www.hnd.usace.army.mil/rtlp/index.aspx.

This report will be made accessible through the World Wide Web (WWW) at URL: http:// www.cecer.army.mil. 


\section{Regulatory Considerations}

\section{Considerations for NEPA Documents}

The National Environmental Policy Act (NEPA, Public Law 90-190) is the basic national charter for protection of the environment. It establishes policy, sets goals (Section 101), and provides means (Section 102) for carrying out the policy. Section 102(2) contains action-forcing provisions to make sure that federal agencies act according to the letter and spirit of the Act. The Council on Environmental Quality (CEQ) regulations implement section 102(2). Their purpose is to tell the federal agencies what they must do to comply with the procedures and achieve the goals of the Act. NEPA procedures must ensure that environmental information is available to public officials and citizens before decisions are made and before actions are taken. NEPA documents must concentrate on issues that are truly significant to the action in question. Integrating the NEPA process into early planning is recommended to give appropriate consideration to potentially significant issues. The consideration that is given to a project depends on the project's scope, public involvement and concern (scoping), and the extent and value of impacted resources.

Title 32 of the Code of Federal Regulations (CFR), Part 651 (32 CFR 651) implements policy and procedures of NEPA and CEQ. Subpart A requires environmental analysis of Army actions affecting human health and the environment; provides criteria and guidance on actions normally requiring Environmental Assessments (EAs) or Environmental Impact Statements (EISs); and lists Army actions that are categorically excluded from such requirements (provided certain criteria are met).

NEPA is a planning statute that stresses an interdisciplinary approach to problem solving. It requires consideration of natural and cultural resources. The NEPA process does not replace the procedural or substantive requirements of other environmental statutes and regulations. Rather, it addresses them in one place (e.g., EA) so the decision-maker has a concise and comprehensive view of major environmental issues. The following sections contain overviews of the "major" environmental legislation. 


\section{Clean Air Act}

The Clean Air Act (CAA) of 1963 as amended (42 U.S. Code [USC] Chapter 85, Air Pollution Prevention and Control) was established "to protect and enhance the quality of the Nation's air resources so as to promote public health and welfare and the productive capacity of its population." The CAA has been amended several times since it was first enacted in 1963. The primary objective of the CAA is to establish federal standards for various pollutants from both stationary and mobile sources and to provide for the regulation of polluting emissions via state implementation plans (SIP). In addition, the amendments are designed to prevent significant deterioration in certain areas where air quality exceeds national standards, and to provide for improved air quality in areas that do not meet federal standards.

Air quality can be affected in many ways by the pollution emitted from a variety of stationary and mobile sources. The Environmental Protection Agency (EPA) has the following sources classified as the six principal pollutants: carbon monoxide, lead, nitrogen dioxide, ozone, particulate matter, and sulfur oxides. The CAA includes specific limits, timelines, and procedures to reduce these pollutants.

The goal of the CAA is to develop National Ambient Air Quality Standards (NAAQS) that protect public health and the environment. Ultimately, the CAA requires sources to meet standards and obtain permits to satisfy NAAQS, Standards of Performance for New Stationary Sources, National Emission Standards for Hazardous Air Pollutants (NESHAPs), and Prevention of Significant Deterioration (PSD) rules.

There are two types of standards: primary and secondary. Primary standards protect against adverse health effects; the secondary standards protect against welfare effects, such as damage to farm crops and vegetation and damage to buildings. Through various programs, the Office of Air Quality Planning and Standards (OAQPS) monitors for criteria pollutants. One such program is the Ambient Air Monitoring Program. Through this program, air quality samples are collected to judge attainment of ambient air quality standards, to prevent or alleviate air pollution emergencies, to observe pollution trends throughout regions, and to evaluate the effects of urban land use, and transportation planning relating to air pollution. 
The EPA tracks air pollution in two ways: air quality and emissions. The CAA, the primary federal statute regulating air emissions, applies fully to the Army and all its activities. The CAA categorizes regions of the United States as nonattainment areas if air quality within those areas does not meet the required ambient air quality levels set by NAAQS. The CAA mandates that new stationary sources, or major modifications to existing stationary sources located in attainment areas, must obtain a PSD permit before beginning any new construction that would generate emissions that exceed the PSD threshold for the six primary pollutants. Army Regulation (AR) 200-1, Environmental Protection and Enhancement, provides information on the Air Program (Chapter 6). The Army air program addresses air quality issues associated with exposure to outdoor air pollutants. The purpose of this program is to manage air emissions to protect human health and the environment, and to comply with all legally applicable and appropriate federal, state, and local air quality control regulations. This chapter covers air quality issues addressed by the Clean Air Act, as amended. Issues concerning asbestos and radon are addressed in Chapters 8 and 9, respectively. Indoor air quality issues and regulations are promulgated by the Occupational Safety and Health Administration. Major air program requirements (from AR 200-1, paragraph 6-3) are provided below.

a. The following objectives will be met in pursuit of the goal of the Army air program:

(1) Identify sources of air emissions and determine the type and amount of pollutants being emitted when required by statute or regulation.

(2) Monitor sources of regulated pollutants to ensure compliance with applicable standards when required by statute or regulation.

(3) Comply with all applicable and appropriate federal, state, interstate, and local requirements respecting the control and abatement of air pollution. Obtain required permits for the construction and/ or operation of regulated sources, including, where required, a federal Title $V$ permit under the CAA.

(4) Procure equipment that meets applicable air quality standards.

(5) Cooperate with federal, state, and local authorities in achieving the goals of implementation plans.

(6) Obtain or develop training and/ or certification for operators of air pollution sources in order to meet statutory and regulatory requirements and minimize emissions from those sources. 
(7) Assess the need for and, if necessary, obtain an installation-wide Clean Air Act Title V Operating Permit.

(8) Assess the need for and, if necessary, make written conformity determinations for Army actions.

(9) Meet the applicable work practice and control technology standards under the Clean Air Act Hazardous Air Pollutants Program.

(10) Develop training and technical certification programs meeting the requirements of Section 608 of the CAA.

b. Ozone Depletion Chemicals (ODC) Elimination.

(1) Develop, fund, implement, and maintain plans to meet the Army established goal for the elimination of procurement, use, and emissions of Class I ODCs by the end of Fiscal Year 2003.

(2) Develop, fund, implement, and maintain plans to eliminate procurement, use, and emissions of Class II ODCs.

(3) Comply with all provisions of the National Defense Authorization Act for Fiscal Year 1993, Section 326.

(4) Document all current and projected ODC-related costs through the Environmental Program Requirements Report process.

(5) Reduce ODC use in all applications to zero as substitutes that meet applicable standards become available.

Installations must consider the effects that planned projects and activities will have on air quality both on and off post. There are two independent legal requirements that address air quality management: (1) NEPA and (2) the general conformity provision of CAA Section 176(c), including EPA's implementation, the General Conformity Rule. Depending on the action and the air quality conformity attainment status of the installation (or other affected property), an installation might have to complete a separate conformity analysis in addition to the NEPA analysis. Under Section 176(c) of the CAA, activities must conform to an implementation plan's purpose of "eliminating or reducing the severity and number of violations" of NAAQS and achieving "expeditious attainment" of such standards. Pursuant to that rule, conformity determinations are required to ensure that state air quality standards would not be exceeded and that the action would comply fully with the SIP. The proponent (installation) compares the emission levels of the proposed action to current baseline emissions. Where increases in emission levels exceed thresholds established in the General Conformity Rule, a conformity determination must be prepared. 
In support of the conformity determination, additional air quality modeling may be required to show more precisely the action's impacts on air quality in the region.

\section{Clean Water Act}

The principle law governing pollution of the nation's surface waters is the Federal Water Pollution Control Act. It was originally enacted in 1948 but with growing public awareness and concern for controlling water pollution the act was revised by amendments in 1972. As amended in 1977, this law became commonly known as the Clean Water Act (CWA). The act established the basic structure for regulating discharges of pollutants into the waters of the United States. It gave the EPA authority to implement pollution control programs such as setting wastewater standards for industry. The CWA also set requirements for water quality standards for all contaminants in surface waters. The Act requires application of technologybased controls on discharge and establishes a national permit program, the National Pollutant Discharge Elimination System (NPDES). The NPDES permit program controls water pollution by regulating point sources that discharge pollutants into waters of the United States. Point sources are discrete conveyances such as pipes or man-made ditches. Individual homes that are connected to a municipal system, use a septic system, or do not have a surface discharge do not need a NPDES permit; however, industrial, municipal, and other facilities must obtain permits if their discharges go directly to surface waters. Over the years, many other programs that were primarily directed at point source pollution, but shifted focus to non-point source pollution, changed parts of the CWA.

Under this Act, federal jurisdiction is broad, particularly regarding establishment of national standards or effluent limitations. The EPA issues regulations containing best practicable control technology (BPT) and best available technology (BAT) effluent standards applicable to categories of industrial sources. Certain responsibilities are delegated to the states, and the Act embodies a philosophy of federal-state partnership in which the federal government sets the agenda and standards for pollution abatement, while states carry out day-to-day activities of implementation and enforcement (Copeland 1999).

Delegated responsibilities under the Act include authority for qualified states to issue discharge permits to industries and municipalities and to enforce permits. The law set a timetable for cleanup of the nation's waters. 
It also required all pollutant dischargers to obtain a permit and meet the conditions of the permit.

The Act embodies the concept that all discharges into the nation's waters are unlawful, unless specifically authorized by a permit, which is the Act's principal enforcement tool. The law has civil, criminal, and administrative enforcement provisions and also permits citizen suit enforcement (Copeland 1999).

A separate type of permit is required to dispose of dredge or fill material in the nation's waters, including wetlands. Authorized by Section 404 of the Act, this permit program is administered by the U.S. Army Corps of Engineers, subject to and using EPA's environmental guidance. AR 200-1 provides information on the Water Resources Management Program (Chapter 2). The Clean Water Act (Section 2-4) states that:

a. The Army will comply with all requirements, substantive and procedural, for control and abatement of water pollution, as outlined in the CWA. Major provisions of the CWA include:

(1) National Pollution Discharge Elimination System (NPDES) Permits.

(2) Pretreatment Standards for discharges to Publicly-Owned Treatment Works (POTWs).

(3) Toxic Water Pollutants.

(4) Sewage Sludge Requirements.

(5) Stormwater.

(6) Non-point Source Pollution Control.

(7) Dredge and Fill Operations.

b. Installations will obtain and comply with all necessary NPDES or state discharge permits.

c. Discharges from industrial activities to Federally-Owned Treatment Works (FOTWs) will comply with the substantive pretreatment requirements applicable to POTWs under the CWA. Army activities should develop a pretreatment program to ensure NPDES permit requirements are met and to improve opportunities for the beneficial use of sewage sludge. 
d. Army activities will provide tenant activities information on pretreatment and wastewater guidelines for non-domestic wastewater discharges to FOTWs and POTWs.

e. Discharges to surface waters will be sufficiently free of toxic pollutants such that the discharge will not have an adverse impact on human health and aquatic life or result in the violation of a NPDES permit.

f. Army activities will follow state approved plans for non-point source water pollution control where applicable and appropriate.

g. Army activities will develop a Stormwater Discharge Prevention Plan in accordance with 40 CFR 125.

h. Army activities will develop a Spill Prevention Control and Countermeasures Plan (SPCCP) in accordance with the CWA Section 311(j).

i. Ship-board or shore-side oil/water separation will be performed before the discharge of ballast water from watercraft. Effluent limitations from watercraft are prescribed by:

(1) The U.S. Coast Guard (33 CFR 159).

(2) The Environmental Protection Agency (40 CFR 140).

(3) Individual states.

(4) Technical Bulletin 55-1900-206-14.

j. Proposed military or civil works activities involving the discharge of dredged or fill material into waters of the United States, including wetlands, will be coordinated with the local USACE district.

k. Army activities will evaluate the use of innovative/ alternative technologies for the treatment of wastewater when proposing projects to construct or upgrade wastewater treatment facilities. Each military construction programming document should reflect the fact that innovative or alternative technology was considered.

1. Active Army, Army Reserve, and Army National Guard installations and facilities, will provide copies of all final NPDES permits received from the EPA, or an authorized state, to their major Army commands, State Adjutants General (where appropriate), and the U.S. Army Environmental Center (USAEC). Civil works activities will provide a copy 
of final NPDES permits to their district Environmental Compliance Coordinator.

m. Military installations and activities will monitor, operate, maintain, repair, and upgrade Army water treatment and collection systems according to:

(1) AR 40-5.

(2) AR 420-46.

(3) TM 5-665.

(4) TM 5-814-1 through 5-814-3.

\section{Wetlands Protection Order}

Wetlands are areas that are inundated or saturated by surface water or groundwater at a frequency and duration sufficient to support a prevalence of vegetation typically adapted for life in saturated soil conditions. Executive Order 11990, Protection of Wetlands, requires federal agencies to provide leadership and take action to minimize the destruction, loss, or degradation of wetlands and to preserve and enhance the natural and beneficial values of wetlands. The Army adheres to this Executive Order with its construction projects. In addition, wetlands management is also a component of the installation Integrated Natural Resources Management Plan (INRMP). INRMPs provide range managers and natural resource managers with strategies and practices to improve land use on Army installations and to ensure proper protection and management of surface water and groundwater resources. AR 200-3, Natural Resources - Land, Forest and Wildlife Management provides the following information on wetlands in paragraph 2-21.

a. Wetlands are of critical importance to the protection and maintenance of living resources, including a significant number of endangered and threatened species, as they provide essential breeding, spawning, nesting, and winterizing habitats for a major portion of the nation's fish and wildlife species. Wetlands also protect the quality of surface waters through impeding the erosive forces of moving water and trapping waterborne sediments and associated pollutants, protect regional water supplies by assisting the purification of surface and ground water resources, maintaining base flow to surface waters through the gradual release of stored flood waters and groundwater, and provide a natural means of flood control and storm damage protection through the absorption and storage of water during high runoff periods. 
b. Executive Order 11990 requires that federal agencies minimize any significant action that contributes to the loss or degradation of wetlands and threat action be initiated to enhance their natural value. It is DA [editor's note: Department of the Army] policy to avoid adverse impacts to existing aquatic resources and offset those adverse impacts which are unavoidable. Additionally, Army will strive to achieve a goal of no net loss of values and functions to existing wetlands, and permit no overall net loss of wetlands on Army controlled lands. Furthermore, the DA will take a progressive approach towards protecting existing wetlands, rehabilitating degraded wetlands, restoring former wetlands, and creating wetlands in an effort to increase the quality and quantity of the nation's wetlands resource base. To meet this requirement, installations will identify and maintain a current inventory of their wetlands resources. Installations should contribute to and reference the National Wetlands Inventory.

c. Action affecting wetlands will require an environmental analysis in accordance with AR 200-1, AR 200-2, and applicable federal and state laws and regulations. U.S. Army COE [editor's note: Corps of Engineers] permits are required under Section 10 of the Rivers and Harbors Act of 1899 prior to commencing any work on structures built in a navigable water of the United States. Such work includes dredging, bulkheads, piers and docks, and bank protection. Corps permits are required under Section 404 of the Clean Water Act for the discharge of dredged and fill material into a water of the United States, including wetlands. The COE regulations in 33 CFR 320-330 (http:// www.usace.army.mil/inet/functions/cw/ cecwo/reg) prescribe the statutory authorities and general and special policies and procedures applicable to the review of applications for COE permits. Before commencing any work in a water of the United States, a district must be contacted and a permit obtained, as appropriate.

The time it takes for a permit to be issued varies depending upon the complexity of the project. Projects that qualify for a Nationwide Permit, General Permit, or Letter of Permission require much less processing time and normally can be issued in a matter of weeks (see Chapter 3 for permitting requirements). Standard Individual Permits require a minimum of 60 to 90 days; however this time could be longer for large projects requiring public hearings or if the proposed work is highly controversial. 
Under Section 401 (of the Clean Water Act), applicants for federal licenses or permits for activities that may result in a discharge into waters of the United States must first obtain certification from the state in which the discharge would originate. The certification must verify that the discharge will comply with the applicable effluent limitations, state water quality standards, and other appropriate requirements. Certification for the construction of a facility must also cover the operation of the facility. These certifications are required for any impacts to wetlands, streams, or water bodies that may be impacted during construction or operation. The State Water Resources Control Board and the Regional Water Quality Control Boards issue water quality certifications pursuant to Section 401 of the CWA. Section 401 certification allows states to take a more active role in wetland decisions. In most cases, the state review is conducted at the same time as the federal agency review. Many states have established a joint permit processing to ensure this occurs. In addition, the Section 401 review allows for better consideration of state-specific concerns.

Section 401 states that "Any applicant for a Federal license or permit to conduct any activity including, but not limited to, the construction or operation of facilities, which may result in any discharge into the navigable waters, shall provide the licensing or permitting agency a certification from the state in which the discharge originates or will originate, or if appropriate, from the interstate water pollution control agency having jurisdiction over the navigable waters at the point where the discharge originates or will originate, that any such discharge will comply with the applicable provisions of sections 301, 302, 303, 306, and 307 of this Act." (http:// www.epa.gov/ r5water/ cwa.htm) This section further states that no license or permit shall be granted until the certification required by this section has been obtained or has been waived.

\section{Sikes Act}

Over the years laws have been enacted to conserve and protect our natural resources. In 1960 the Sikes Act (Public Law 86- 797) was the first legislation to promote the conservation and management of natural resources on military lands. It not only provided the protection and enhancement of fish, wildlife, and ecosystems on which they depend, but it also promoted the use of these lands and game for public recreation. The Sikes Act, as amended, requires military facilities to provide access to natural resources, as appropriate and consistent with the military mission. The Act designated the responsibility to the military to promote natural resources con- 
servation and rehabilitation on its lands. The strategy to preserve and manage natural resources is described in the installation integrated natural resources management plan. The INRMP is developed in collaboration with the U.S. Fish and Wildlife Service (FWS) and the state agencies. The INRMP integrates the military mission with the installation's natural resources management plan, identifies possible conflicts between natural resources and the military mission, and indicates the actions needed to meet federal and state regulations. The mandatory nature of the INRMP preparation and implementation also triggers the requirements of NEPA.

AR 200-3 enumerates the Army policy for natural resources management. This regulation provides the framework for the conservation, management, and rehabilitation of natural resources on Army lands in conjunction with federal statutes and regulations and provides information on INRMPs. Chapter 9 of AR 200-3 states:

a. Integrated natural resources management plans, as referenced to in the Sikes Act, will be developed and maintained for all Army installations. These plans will be prepared, implemented, and monitored by natural resource management professionals. The plans will be coordinated with appropriate Federal, State, and local natural resource managers and agencies with natural resources expertise and will be made available for public comment. The plan will include, as appropriate, parts: I General; II Land Management and Grounds Maintenance; III Forest Management; IV Fish and Wildlife Management; and V Outdoor Recreation. Plans will be used to assist planners and implementers of mission activities as well as natural resource managers. The INRMP will be a component and supporting element of the installation master plan. New and continuing mission activities that impact natural resources will be coordinated with appropriate natural resources managers.

b. A natural resources management plan is integrated when the following criteria are met:

(1) All renewable natural resources and areas of critical or special concern are adequately addressed from both technical and policy standpoints.

(2) The natural resources management methodologies will sustain the capabilities of the renewable resources to support military requirements. 
(3) The plan includes current inventories and conditions of natural resources; goals; management methods; schedules of activities and projects; priorities; responsibilities of installation planners and decision makers; monitoring systems; protection and enforcement systems; land use restrictions, limitations, and potentials or capabilities; and resource requirements including professional and technical manpower.

(4) Each plan segment or component (that is, land, forest, fish and wildlife, and outdoor recreation) exhibits compatible methodologies and goals including compliance with the Endangered Species Act and applicable Endangered Species Management Plans.

(5) The plan is compatible with the installation's master plan, pest management plan, and Master Training Schedule.

c. 16 USC 670a provides a requirement whereby the Army installation, the FWS and the host state cooperate in planning, maintaining, and coordinating fish and wildlife management activities on installations. A cooperative plan (that is Part IV Fish and Wildlife Management of the Natural Resources Management Plan) will be signed by an installation commander, the U.S. Fish and Wildlife Service, and the appropriate State agency, only after ensuring compatibility with the applicable integrated natural resources management plan. Fish and Wildlife Cooperative plans will be reviewed annually by cooperators and revised no less than every 5 years.

\section{Endangered Species Act}

A critical step in conserving our most vulnerable natural resources was the enactment of the Endangered Species Act of 1973 (Public Law 93-205). This legislation ensured the protection of plants, wildlife, and fish threatened with extinction and the ecosystems upon which they are dependent. The Act was also vital in promoting cooperation between federal, state, and local agencies in the conservation of natural resources.

The ESA includes definitions of relevant terms. "Endangered species" is a species that is at risk of extinction throughout all or a significant section of its range. The exception to this definition is pests of the Class Insecta that pose a significant risk to humans. "Threatened species" is a species at risk of becoming endangered in the near future throughout all or a significant section of its range. "Critical habitat" is the specified area within a geographic area that encompasses the physical and biological traits necessary to conserve the species at the time of listing and may necessitate excep- 
tional management attention. Critical habitat can also be a specified area not within the geographic area at the time of listing, which is also deemed necessary to conserve the species. "Federally listed" is not a term defined by the ESA; it refers to species that have been designated as endangered or threatened at the federal level.

The ESA provides a means to conserve the ecosystems upon which endangered and threatened species depend. Under the ESA, the National Marine Fisheries Service (NMFS) and the FWS are responsible for compiling lists of threatened and endangered (TES) species, for issuing biological opinions regarding federal activities, and for enforcing statutory and regulatory provisions.

According to Section 7 of the ESA, when a federal agency action/ activity may affect (either positively or negatively) a listed or proposed species, or critical habitat, the agency must have formal consultation with the FWS or the NMFS. In conjunction with the consultation, a Biological Assessment (BA) or other pertinent documents must be included. Using the most current scientific and commercial data, a BA is developed by the installation to determine if any listed species or critical habitat may be affected by a proposed activity. The result of the formal consultation is a Biological Opinion by the FWS or NMFS. The biological opinion states the likelihood that the proposed activity will jeopardize the existence of the species and/ or destroy or diminish the quality of critical habitat. If it is found that the activity will impact a listed species or critical habitat, the potential impacts are indicated, measures to minimize the effects are listed, and the terms and conditions needed to comply are documented. An exemption from the ESA may be requested by DoD.

AR 200-3, Chapter 11, provides guidance to the Army on endangered/ threatened species. Section 11-1 (Part a) states that all Army land uses, including military training, testing, timber harvesting, recreation, and grazing, are subject to ESA requirements for the protection of listed species and critical habitat. Part b states that "In fulfilling its conservation responsibilities under the ESA, the Army will work closely and cooperatively with the Federal agencies charged with enforcement of the act: the U.S. Fish and Wildlife Service (FWS) and the National Marine Fisheries Service (NMFS).... Installations will routinely seek informal FWS or NMFS review of installation plans. If there is any question whether an Army action may affect a listed species or critical habitat, DA personnel should informally 
consult with the NMFS or FWS to determine the need for formal consultation."

Section 11-2 of AR 200-3 imposes five primary requirements upon the Army. These are:

1. Requirement to conserve listed species (refer to ESA Section 7(a)(1)).

2. Requirement not to "jeopardize" listed species (refer to Section 7(a)(2)).

3. Requirement to "consult" and "confer" (refer to Section 7(a)).

4. Requirement to conduct a biological assessment (refer to Section 7(c)). This requirement is for major construction and other activities having similar physical impacts on the environment if: (1) the impacts will significantly affect the quality of the human environment as referred to in NEPA and (2) if any listed species or critical habitat is present in the area directly or indirectly affected by the action (action area).

5. Requirement not to "take" listed fish and wildlife species or to remove or destroy listed plant species. Under Section 9 of ESA, "take" means to "harass, harm, pursue, hunt, shoot, wound, kill, trap, capture, or collect or attempt to engage in any such conduct" with respect to listed fish and wildlife. It includes significant habitat modification or degradation that kills or injures wildlife by significantly impairing essential behavioral patterns, including breeding, feeding, or sheltering. Section 9 further makes it unlawful to remove and reduce to possession any listed plant from areas under federal jurisdiction or to maliciously damage or destroy any listed plant in such areas.

Section 11-3 (Part b) states that "Proponents of Army actions will coordinate with the installation's natural resources staff early in the planning stage of projects and activities to identify potential conflicts with the conservation of listed and proposed species. The installation engineer and the environmental directorate, where applicable, will integrate endangered species management and installation planning functions to avoid conflicts with ESA requirements."

Section 11-5 provides guidelines on the Endangered Species Management Plan and Guidelines (ESMG). Part a, General Requirement (1) states that "Installations will prepare ESMPs [Endangered Species Management Plans] for listed and proposed species and critical habitat present on the installation, including areas used by tenant organizations. Installation ESMPs are the Army's primary means of ensuring ESA compliance and 
balancing mission requirements. Army endangered species management will give first priority to the preparation and resourcing of installation ESMPs including related inventories. HQDA and MACOMs will assist installations in obtaining adequate funding and support to effectively develop and implement ESMPs". Subpart (5) states that all proposed ESMPs and ESMGs are subject to the requirements of NEPA, in addition to the consultation requirements of Section 7 of the ESA.

Part b, Installation ESMPs (4), states that preparation of ESMPs requires a systematic, step-by-step approach. The species' population size (current and goal), habitat (current and goal), and training and other mission requirements (present and future) must be identified. Detailed evaluation of these factors and their interrelated impacts are required as a first step in the development of ESMPs. The length and detail of installation ESMPs are dependent upon the complexity of the management problems associated with the species and its habitat. For additional information on what the ESMP will include, refer to AR 200-3, Chapter 11-5, part b.

Section 11-6, Part f, NEPA compliance, states that NEPA, implemented by AR 200-2, applies to actions taken in managing listed and proposed species and critical habitats. Consultation under Section 7 of the ESA does not replace compliance with NEPA requirements. In preparing and staffing ESMPs, proponents must ensure that they satisfy NEPA requirements. Proponents will normally prepare environmental assessments for activities, including ESMPs and ESMGs, that affect federal or state listed or proposed species, or critical or proposed critical habitat. NEPA requires an environmental impact assessment if an ESMP or ESMG will significantly affect a listed or proposed species, or critical habitat or proposed critical habitat, or the human environment (refer to AR 200-2, para 6-2). Consultation, conference, and biological assessment procedures under Section 7 of the ESA should be consolidated with NEPA procedures to the maximum extent feasible. Simultaneous compliance with NEPA and ESA procedures minimizes duplication of effort and avoids delay. Proponents may combine ESA and NEPA documentation to reduce paperwork (such as the biological assessment and environmental assessment) so long as the requirements of both statutes are met. For additional information on consultation with FWS, refer to Section 11-7 of AR 200-3. The ESA coordination process is also provided in Figure 11-1 of AR 200-3. 


\section{Comprehensive Environmental Response, Compensation, and Liability Act (CERCLA)}

The Comprehensive Environmental Response, Compensation, and Liability Act (CERCLA) of 1980 (Public Law 96-510) provides a mechanism to clean up contaminated sites and hold potentially responsible parties accountable for cleanup costs. CERCLA authorizes the EPA to force parties that were responsible for the release of hazardous substances to finance cleanups on the contaminated site. CERCLA created a tax on the chemical and petroleum industries and provided broad federal authority to respond directly to releases or threatened releases of hazardous substances that may endanger public health or the environment. A fund was created from taxes generated by this program. This fund is commonly called the "Superfund". It was reauthorized in 1986 as the Superfund Amendment Reauthorization Act (SARA).

There are four broad categories of potentially responsible parties (PRPs) that may be held liable for paying for the CERCLA cleanup costs if they contributed any amount of hazardous substance to the contaminated site:

1. Current owners or operators of the site at which hazardous substances were disposed.

2. Past owners or operators of a site at the time hazardous substances were disposed of at the site.

3. Anyone, including generators, who arranged for the disposal, transport, or treatment of hazardous substances found at the site.

4. Transporters or anyone who arranged for transport of hazardous wastes to a facility.

Unlike other environmental statutes, there is no permit required. CERCLA does not attempt to prevent pollution from occurring, but rather addresses areas that have already been contaminated. The primary provisions of CERCLA, as amended by SARA, are to: (1) Provide authority for cleanup of abandoned or uncontrolled hazardous waste sites; (2) Provide emergency response to releases of leaks or spills of hazardous substances; (3) Provide a legal framework to identify PRPs and ensure that the responsible parties pay for the site cleanup; and (4) Establish a trust fund for cleanup when no PRPs could be identified. This trust fund is provided for by a tax on chemi$\mathrm{cal}$ and petroleum industries. If a site is identified that has potential to contain hazardous substances, it is entered into the EPAs Comprehensive Environmental Response, Compensation, and Liability Information Sys- 
tem (CERCLIS). To ensure that the most serious hazardous waste sites are addressed, the law calls for a National Priority List (NPL) to be assembled by the EPA. It also calls for EPA to develop a hazard ranking system to construct the NPL, which scores factors as the quantity and nature of hazardous waste present; the likelihood of contamination of ground water, surface water, and air; and the proximity of the site to population and sensitive natural environments.

Examples of superfund sites include: abandoned warehouses, manufacturing facilities, processing plants, and landfills.

CERCLA authorizes two kinds of response actions: (1) Short-term removals, where actions may be taken to address releases or threatened releases requiring prompt response; and, (2) Long-term remedial actions, that permanently and significantly reduce the dangers associated with releases or threats of releases of hazardous substances that are serious, but not immediately life threatening. These actions can be conducted only at sites listed on EPA's NPL. CERCLA also enabled the revision of the National Contingency Plan (NCP). The NCP provided the guidelines and procedures needed to respond to releases and threatened releases of hazardous substances, pollutants, or contaminants. NCP also established NPL.

\section{National Historic Preservation Act}

The National Historic Preservation Act (NHPA) of 1966 as amended (36 CFR 800) established the federal government's policy to provide leadership in the preservation of historic properties and to administer federally owned or controlled historic properties in a spirit of stewardship. Section 106 of NHPA requires federal agencies to take into account the effects of their undertakings on historic properties. Section 106 and its implementing regulations state that an undertaking has an effect on a historic property when it could alter those characteristics of the property that qualify it for inclusion in the National Register of Historic Places (NRHP). An undertaking is considered to have an adverse effect on a historic property when it diminishes the integrity of the property's location, design, setting, materials, workmanship, feeling, or association. According to Section 106, the agency must decide if the undertaking is the kind of action that could affect historic properties. If there is an undertaking, a NEPA review may be initiated at this stage. If historic properties that are included in the NRHP or meet the criteria for the National Register are potentially af- 
fected, an appropriate State Historic Preservation Officer must be identified to consult with during the process.

AR 200-4 (1998), Chapter 2 identifies the basic compliance requirements associated with the major federal cultural resources laws and regulations applicable to Army activities. Chapter 2-2 provides information on complying with NEPA. Part a states “...the proponents of Army actions will ensure that cultural resources are fully considered when preparing NEPA documents." Part b states that "NEPA documents will include a comprehensive assessment of the impacts of proposed Army actions or activities on cultural resources." Part c states that "Impact assessments under NEPA must consider the effects of proposed Federal actions on cultural resources and the effects on Indian tribes, Native Hawaiian Organizations, Native Alaskans, and other ethnic and social communities to whom the cultural resources may have importance. The information needed to make such impact assessments may be acquired from information developed as a result of compliance with cultural resources statutes, regulations and Executive Orders."

Chapter 2-3, Part a, states: "The installation commander shall administer, manage and treat historic properties in accordance with NHPA. The installation commander shall also identify, evaluate, and nominate historic properties for listing in the National Register of Historic Places consistent with the policies and guidelines in this regulation and DA Pam 200-4." The pamphlet establishes a comprehensive cultural resources planning and management strategy for the Army, provides an overview of statutes and regulations, as well as information regarding ICRMPs. The ICRMP integrates the entirety of the installation cultural resources program with the ongoing military mission, and allows identification of potential conflicts between installation's mission and cultural resources. The ICRMP is a 5-year plan for compliance with cultural resources statutes, executive order, regulations and other requirements. ICRMPs are subject to NEPA analysis and documentation requirements and should be implemented by appropriate level of NEPA documentation. Information and findings obtained through compliance with cultural resources statutes and regulations should be integrated into the concurrent NEPA compliance process and documents. According to AR 200-4 (Chapter 4), it is recommended that an EA and a Finding of No Significant Impact (FONSI) be prepared to support and implement the ICRMP. Refer to Chapters 2-2 and 2-3 in AR 200-4 for additional information on NEPA and NHPA, respectively. 


\section{Overview of Permitting Requirements}

A wide range of permit processes have been put in place and designed to ensure that disturbing activities comply with state and federal laws. It is a misconception that federal agencies do not need permits for groundbreaking activities.

Multiple permits for both large- and small-scale projects generally are needed and are dependant on site conditions. AR 200-1, AR 200-2, AR 200-3, and AR 200-4 all address areas such as the Sikes Act and Clean Water Act that may require permits for construction or other grounddisturbing activities. Generalized permits that typically are required and applicable to range construction projects are: NEPA 106, 404, 401, Environmental Protection Agency (EPA) Construction General Permit, and applicable state water, erosion, and fish/ wildlife/ game permits.

The process of submitting and obtaining permits can at times be confusing, time consuming, and convoluted. Seek out state environmental offices for help to determine which permits will be required for the proposed activity. At the earliest time seek input and advice from the installation environmental office. This will help develop a comprehensive plan for the range project.

Keep in mind that it is not uncommon for it to take 3-4 months to obtain a state-issued permit. It can at times take over 12 months to obtain a federal permit, excluding the time required to complete the permit application itself.

\section{CWA Section 404 Permit}

The basic premise of this permit program is that no discharge of dredged or fill material can be permitted if a practical alternative exists that is less damaging to the aquatic environment or if the nation's waters would be significantly degraded. In other words, when you apply for a permit, you must show that you have:

- taken steps to avoid wetland impacts when and where possible/ practical;

- minimized potential impacts to wetlands; and 
- provided compensation for any remaining, unavoidable impacts through activities to restore or create wetlands.

Regulated activities are controlled by a permit review process. An individual permit is usually required for potentially significant impacts. However, for most discharges that will have only minimal adverse effects, the United States Army Corps of Engineers (USACE) often grants up-front general permits. These may be issued on a nationwide, regional, or state basis for particular categories of activities (for example, minor road crossings, utility line backfill, and bedding) as a means to expedite the permitting process.

It is critical that a 404 permit is secured when starting the initial process for siting and planning of any range or ground-disturbing activity that lies within or near wetland areas and/ or will directly cross or discharge into an aquatic environment. Most states have "blanket/ general" permit agreements for limited acreage $(<1 / 10$ of an acre) or linear stream length $(<600$ feet) with the USACE and EPA for the issuing of both 404 and 401 permits. Pre-permitting consulting is generally available and highly recommended prior to submitting permit applications to your state office or district. See individual state environmental, water quality, or natural resources departments for permit application and processes.

\section{CWA Section 401 Permit}

This is a state-issued permit that triggers a 404 permit. Section 401 of the CWA requires applicants to obtain a 401 water quality certification "permit" from the state having jurisdiction over the water body potentially affected by the activity in order to obtain a 404 permit. The USACE retains all authority to issue 404 permits for wetlands that are not considered isolated (jurisdictional wetlands) as well as other waters of the United States. Section 401 permits are required for any impacts to wetlands, streams, or water bodies that may be impacted during construction. Typical projects needing permits are: low water crossings, roads or trails that traverse through wetlands or cross streams, altered hydrology that will increase or decrease flow in or out of wetlands, streams, and other water bodies. See your individual state environmental, water quality, or natural resources departments for permit application and processes. 


\section{EPA Construction General Permit}

Construction activities (including other land-disturbing activities) that disturb 1 acre or more are regulated under the National Pollutant Discharge Elimination System (NPDES) stormwater program. On March 40, 2005, new regulations came into effect that extended coverage to construction sites that disturb 1 to 5 acres in size, including smaller sites that are part of a larger common plan of development or sale. Sites disturbing 5 acres or more were regulated previously.

Operators of regulated construction sites are required to develop and implement stormwater pollution prevention plans and to obtain permit coverage from an authorized state or from the EPA if the state is not authorized by EPA to issue NPDES permits.

Most states are authorized to implement the NPDES permit program, including the stormwater program. Use this list to determine if your state operates the NPDES stormwater program. Please contact your permitting authority to determine the specific requirements that apply to you.

\section{State Erosion Control Permits}

Most states and counties have some type of soil erosion and sediment program that requires erosion and sediment control permits for construction or ground-breaking activities. See your state environmental, water quality, or natural resources departments for permit application and processes.

\section{National Historic Preservation Act, Section 106}

All construction or ground-breaking activities require federal agencies to take into account the effects of the undertakings on historic properties and to allow the Advisory Council on Historic Preservation a reasonable opportunity to comment.

The State Historic Preservation Officer/Tribal Historic Preservation Officer (SHPO/THPO) needs to be consulted during the process and will determine if the activity has or has no potential to affect historic properties. If it is determined there is no potential for negative effect, the agency has no further Section 106 obligations and the activity can start. If the SHPO/THPO makes an assessment of adverse effects, the involved parties 
will begin consultation to determine the best way to avoid, minimize, or mitigate the adverse effects.

Consult with your installation Cultural Resources Manager to obtain proper permit applications and for guidance.

\section{Endangered Species Act}

Section 7 of the Endangered Species Act directs federal agencies to take into account the effects of the undertakings on threatened and endangered species. Consult with your installation wildlife biologist, botanist, or threatened and endangered species department to determine if impacts to any species or habitat could result for the proposed activity. Consultations with Fish and Wildlife Service (FWS) may be required and permitting needed. All 50 states have fish and game/ wildlife agencies that work in cooperation with the FWS district offices on the incidental take permitting process. Many states also have additional laws and regulations that protect endangered species. Use the national endangered species tool (NEST) to find out more about the rules in your state and to find points of contact at the FWS district office and state fish and game/ wildlife agency. 


\section{Berms}

\section{Checklist for Planning and Siting Berms}

- Obtain topographic maps, soil maps, and aerial photographs of proposed construction site.

- Ensure that proposed site is not located in a 100-year floodplain or near any surface or shallow subsurface water.

- Wetland delineation may be required.

- See Installation Environmental Office

o Construction within or near a wetland or water body requires permitting $(404,401$, and other pertinent state and local permits).

- See DPW, Environmental Office, and ITAM Office

Identify potential problems that may arise from noise, dust generation, and ricochets in and around the proposed site. If problems are discovered, restrictions and or additional structures may be required to mitigate conflicts if site cannot be move to more suitable location.

- Ensure that no TES are located at the site and that the area has been surveyed for cultural resources.

- TES or critical habitat may require a Biological Assessment (BA), Environmental Impact Statement (EIS), and/ or Environmental Assessment (EA).

- See Environmental Office, TES Office, and ITAM Office

o Construction permits will require NEPA 106 documentation.

- See Environmental Office or Cultural Resources Manager

Identify a location that will minimize the embankment dimensional parameters based on line of sight requirements and allow firing positions.

a Collect line of sight data from defilades or other firing positions to determine required berm height.

口 Obtain all necessary permits.

口 Ensure that proposed sight is as close to perpendicular to the trajectory from firing positions as possible to minimize ricochets.

口 Observe potential line of sight problems from existing vegetation. A wooded area will probably continue to pose a problem if controlled burning is restricted on the range. 
- Determine physical characteristics (engineering characteristics) of the proposed site subsurface soil to determine site suitability for an embankment

- Determine the slope angle for the site based on topography and soil physical characteristics (maximum slope allowable 3:1) and estimate soil volume needed.

- Ensure soils at the site can be used to construct the berm from engineering soil assessments. If soils are inadequate, soil will have to be brought in from elsewhere and will significantly increase the cost of the berm construction.

a Determine the hydrological impact of larger berms and identify future potential erosion sites down gradient of the embankment that may present maintenance challenges.

a Remove topsoil from the berm site for later reuse on the constructed embankment to enhance revegetation of the embankment.

口 Determine acceptable species for planting on berm faces. Adequate vegetation is necessary to reduce erosion and subsequent maintenance loads and should be tolerant to periodic fires. 


\section{Checklist for Operation and Maintenance of Berms}

ㅁ Ensure berm is still performing satisfactorily after every major firing exercise. Look for significant craters, cavities, etc. that could cause the berm to fail if left alone.

- Inspect supporting superstructure components for damage, if present. If damage is discovered, determine if degradation requires repair and will cause failure of the overall structure and requires repairs.

口 If earthwork is required, ensure that fill soil is acceptable, compacted to desired density, slope aspect is maintained, and faces are seeded when finished.

a Determine if erosion control structures are performing as designed. Rebuild/ replace any failing soil conservation structure as necessary to maintain embankment integrity.

- Ensure that adequate vegetation is maintained on berm faces. If pockets of bare soil are found, soil filling and reseeding can be used to quickly reduce the potential for erosion.

- Periodically, mow berm slopes to increase basal cover of forbs and grasses, remove woody species and reduce fine fuel load.

a Maintain height of vegetation to eliminate line of sight interference from firing points.

口 Determine if dust generation is acceptable. Substantial dust generation may indicate inadequate vegetative cover. If a quick fix is necessary, a dust palliative can provide a short term reduction in dust.

- Ensure bullet traps and other associated products have not outlived their useful life. Remove, empty, and/ or replace as instructed to reduce potential for soil contamination. 


\section{Section 1: Planning and Siting}

When siting berms, the most important consideration should be to maintain an effective target backstop while minimizing the necessary earthwork and offsite migration of berm components. To best minimize potential siting conflicts, berms and firing positions such as defilades should be sited simultaneously to determine what layout best maintains line-of-sight while minimizing potential environmental problems. The most important part of the berm is the soil used in its construction. High-quality berms are much less prone to failure due to blast forces and subsequent erosion and have significantly lower maintenance requirements.

\section{Topography}

Topography is extremely important when siting a berm, because the lineof-sight from firing positions will dictate how high the berm must be. An ideal condition would have both berms and firing positions located on a relatively level area with the berm on a slightly higher elevation than the positions to minimize earthwork. Avoid siting berms on crests of high hills, mesas, or ridges, as these areas will be highly erodible. Berms sited downslope of firing positions will require a greater height to minimize overshots.

Additionally, berms should not be sited in or near floodplains as erosion from the berms will potentially create water quality issues. Other surface waters should be avoided as well.

\section{Geology/Soils}

A thorough knowledge of the geologic and soil properties of any potential berm site is required in choosing ideal locations. Important geologic information to gather at any potential site is the type and depth of bedrock material, depth of the water table, and locations of any karst formations.

At the site, a thorough investigation of soil properties is needed to ensure their suitability. Soil compactibility is very important and if the natural soil at the site is inadequate, soil with desirable properties may have to be brought to the site. Erosion potential of the soil is also important; berm soils should be as resistant to erosion as possible. Berm soils should also be capable of supporting vegetation. Inadequate soils will be more prone 
to erosion and may require a layer of topsoil or soil amendments in order to promote growth.

\section{Climate}

Knowledge of climatic factors such as precipitation events is useful in locating suitable berm sites. An area that is prone to flooding or high runoff may not be suitable. Prevailing winds and average wind speed are also important due to the potential for dust generation from berms. Berms should not be place upwind from an area where dust can cause health or safety problems. Air quality impacts for fugitive dust generation from construction and usage may require permits. Temperature is important as well. Berms located in areas with hot, dry summers may benefit from placement in a north-south direction to limit exposure of faces to the south. However, if the back of the berm is reinforced with concrete or otherwise does not require vegetation, the active face of the berm will benefit most from a northerly aspect.

\section{Water Resources}

Berms should not be located near any bodies of surface water due to potential for high erosion and sediment transport. Berms should not be placed in 100-year floodplains. Buffer zones should be established if berms must be sited in proximity to water bodies. Nearby wetlands may require protection or construction of mitigated wetlands in another area. Drainage patterns in the watershed where the berm will be sited should be assessed to minimize erosion potential. Further, berms should not be sited in areas with high water tables since waterlogged soils can lead to damage or failure. Movement of excess water should be determined and it should be directed to flow into a suitable off-site location.

\section{Threatened/Endangered Species}

The presence of TES or critical habitat needs to be determined at each potential site. If TES are present in the vicinity, the first consideration should be to avoid constructing a berm because special requirements may have to be met, such as EIS, EA, and BA documentation. Certain restrictions may be imposed if noise, dust, or other activities associated with the berm interfere with TES. 
The presence of critical habitat should be easier to overcome as these areas are easier to avoid due to their more permanent residence. If avoidance is not possible, other restrictions may be required, such as seasonal closure during reproduction.

\section{Cultural Resources}

Potential sites should be thoroughly surveyed for the presence of culturally significant sites as NEPA 106 permits are required before construction.

\section{Vegetation}

The most important consideration for vegetation in siting a berm is lineof-sight. If natural vegetation in the area interferes with line-of-sight, it will most likely continue to pose problems in the future. Areas where grasses and forbs can be planted and maintained are a more desirable alternative to woody vegetation. Burning the area to maintain line-of-sight is cost effective and fast. Areas where burning is restricted may not be the best choice for a range because fires can be expected due to the nature of the activity and because of increased maintenance requirements without fires. The presence of riparian vegetation often indicates a nearby source of surface water and should be investigated to determine the potential for water quality degradation. Vegetation in potential areas should also be investigated to determine the presence of TES habitat and to assess the potential for revegetation once construction is completed. Vegetation can also be important in mitigating dust and noise, and naturally occurring vegetation should be assessed for potential utilization around the proposed site.

Observing existing vegetation on potential sites is also an important assessment tool. Soils with thick vegetative cover are capable of supporting future plant growth, are more resilient to disturbance, and give a good indication of how well seeds will establish once any construction or disturbance is completed. Areas with sparse vegetation may require greater effort to support desired vegetation, such as importing suitable topsoil or selecting more adaptive vegetation when reseeding.

\section{Noise}

Berms should not be sited in areas where noise propagation is a concern, such as near installation edges with dense neighbor populations. 


\section{Ricochets}

Berms should be positioned in such a way that they are as close to perpendicular as possible to the firing positions on that particular range to lower the potential for ricochets. Berms should also be sited in locations such that a ricochet will not pose a hazard outside that range. If the potential for off-range ricochets exists, side berms or other structures may be required and debris removal will need to occur more frequently.

\section{Section 2: Design and Construction}

When constructing a berm, the most important factor to consider is adhering closely to official design guidelines. Berms often fail due to excessively steep slopes, inadequate vegetative cover, poorly cohesive soil types, and insufficient soil compaction. Ensuring that the designs are followed will decrease maintenance requirements and extend the life of the berm. The most efficient means to monitor constructioin is through continuous inspection and testing.

\section{Range Structure Type}

The intended use of the berm will have a major impact on width, height, shape, slope, and cover of the berm. Mover berms are often constructed with a retaining wall in the back with a targetry track immediately behind. This is sometimes found with stationary berms with pop-up targets. The simplest design is a stationary berm shaped like an isosceles triangle (each face with identical slopes). Berm width will be determined by soil type, substratum core composition (if present), ballistic needs, and height requirements to meet a minimum slope. Topography, line of sight, and safety concerns will dictate the height of the berm to minimize overshots. The ideal slope of a berm is 3:1, but often it is greater due to space constraints and earth-moving costs. However, slopes should be as low as possible because steeper slopes require significantly higher maintenance. Vegetative cover should be encouraged at all times during and after the construction process. Berms lacking sufficient vegetation can degrade rapidly and could be unfit for use even before construction is finished. Fastgrowing, dense vegetation such as grasses are ideal because they are very effective at stabilizing the soil. Small-arms berms may support a synthetic cover but large caliber weapons will easily destroy most commercially available synthetic soil covers and vegetation is recommended on these 
berms. However, a combination of both can work well when attempting to stabilize soil until adequate vegetative cover develops.

\section{Soil Type}

Soil type is perhaps the most important aspect of berm design and construction as it affects all other attributes. Highly cohesive compacted soils have superior strength and shearing resistance and enable greater heights, steeper slopes, and longer usage before requiring maintenance.

\section{Munitions Capture}

Many different products can be incorporated into berm designs that aid in munitions capture and ricochet reduction. Bullet traps can collect small caliber projectiles for recycling. Vegetated filter strips and/ or mulch strips can be placed along the berms in contours and around the base to slow migration of munitions from the site in sediments.

\section{Vegetation}

Vegetation should be maintained at all times to reduce erosion. Selection of appropriate species is extremely important to ensure adequate cover and can be obtained from a variety of sources, including VegSpec (link available in Appendix B) and the local Natural Resources Conservation Service office.

\section{Dust Control}

During construction, steps should be taken to minimize dust generation, such as applying palliatives to bare soil, maintaining vegetative cover, and halting construction on windy days.

\section{Erosion Control}

Designing adequate erosion control for berms will significantly lower the maintenance requirements. Windbreaks will protect exposed soils from wind erosion and vegetation, wattles, filter strips, and mulch strips will decrease water erosion. During construction, silt fences can be used to keep soil on site and fabric or mulch can be used to keep soil in place. 


\section{Section 3: Operation and Maintenance}

Berms generally require significant maintenance due to their intended usage. However, maintenance requirements can be reduced simply by ensuring that the berms are constructed properly and by addressing small problems before they become much larger.

\section{Erosion}

Exposed soil needs to be kept at a minimum to reduce water runoff velocity and limit erosion. Reseeding affected areas is quick and cheap and often will reduce the risk of erosion to berm faces. If erosion control structures are used, periodic checking to ensure proper function will significantly reduce the potential for failure. If mulch or filter strips are damaged, proper reconstruction will be required. Cavities and other damage to berm faces should be filled and compacted as soon as possible using acceptable fill materials.

\section{Vegetation}

Maintaining vegetation on berms is very important for reducing erosion of the slopes. Mowing will maximize basal cover and reduce fine fuel load. Line of sight should also be maintained at all time to minimize missed shots.

\section{Dust Control}

If substantial dust is generated from berms, a dust palliative applied to the berm face may provide a short-term reduction in dust. Windbreaks should be maintained for this purpose and any problems with trees or other windbreak vegetation should also be addressed.

\section{Bullet Collection}

Bullet traps and associated products should not be used past their recommended shot capacity or shelf life. Timely removal of projectiles will prevent chemical degradation and migration off site.

\section{Section 4: Closure}

Closure of berms will most likely occur when an entire range is closed. Berms with low slopes and adequate vegetative cover can probably be left 
intact. Berms with steep slopes, low vegetative cover, and significant erosion problems will probably require smoothing and reseeding. If contamination from munitions is present, berm soil will require remediation or disposal in a designated landfill. 


\section{$5 \quad$ Firing Points}

\section{Checklist for Planning and Siting Firing Points}

- Obtain topographic maps, soil maps, and aerial photographs of proposed construction site.

- Ensure that proposed site is not located in a low-lying area subject to frequent flooding or water inundation or near any surface or shallow subsurface water. Proper drainage is important so that water does not collect in the position and interfere with training.

- Wetland delineation may be required.

- See installation Environmental Office.

- Construction within or near a wetland or water body requires permitting $(404,401$, and other pertinent state and local permits).

- See DPW, Environmental Office, and ITAM Office.

口 Determine the depth and type of bedrock. Soft, shallow bedrock will increase maintenance requirements, as blast forces will easily damage bedrock.

a Identify potential problems that may arise from noise and dust generation in and around the proposed site. If problems are discovered, restrictions and or additional structures may be required to mitigate conflicts if the site cannot be moved to a more suitable location.

- Ensure that no TES are located at the site and that the area has been surveyed for cultural resources.

o TES or critical habitat may require a Biological Assessment (BA), Environmental Impact Statement (EIS), and/ or Environmental Assessment (EA).

- See Environmental Office, TES Office, and ITAM Office. o Construction permits will require NEPA 106 documentation.

- See Environmental Office or Cultural Resources Manager.

a Identify a location that will minimize the firing point dimensional parameters based on line-of-sight requirements and prospective target positions.

口 Obtain all necessary permits.

Collect line-of-sight data from defilades or other firing positions to determine required berm height.

- Ensure that proposed site is as close to perpendicular to proposed berm site as possible to minimize ricochets. 
口 Determine physical characteristics (engineering characteristics) of the proposed site subsurface soil to determine site suitability for firing position

- Determine the slope angle for the site based on topography and soil physical characteristics (maximum slope allowable 3:1) and estimate soil volume needed.

- Ensure soils at the site can be used to construct the firing position from engineering soil assessments. If soils are inadequate, soil will have to be brought in from elsewhere and will significantly increase the cost of the berm construction.

口 Remove the topsoil from the firing position site for later reuse on the constructed firing position and surrounding area to enhance revegetation of the embankment.

口 Observe potential line-of-sight problems from existing vegetation. A wooded area will probably continue to pose a problem if controlled burning is restricted on the range.

- Determine acceptable species for planting on faces. Adequate vegetation is necessary to reduce erosion and subsequent maintenance loads. 


\section{Checklist for Operation and Maintenance of Firing Points}

Observe firing points for damage after every major storm event and every major training activity.

Ensure line-of-sight is maintained and no obstructions are present.

- Address any rutting problems immediately as they will affect the training capacity of the position.

- Determine if erosion or other damage has occurred to the face of the position and take necessary steps to fix the problem.

Ensure that blast mat is secured and subsurface materials are providing the necessary level of support.

口 Determine if bumper or retaining wall has been damaged by collisions and make any necessary repairs.

- Ensure that dust generation is acceptable during usage and take necessary steps, such as applying palliative, if dust becomes a problem.

口 Determine if vegetation is adequately maintained in the vicinity of firing point. Mowing on and around the face may be necessary to decrease fine fuel load, increase basal cover, and maintain line-ofsight. 


\section{Section 1: Planning and Siting}

When siting firing points, the most important consideration should be to maintain line-of-sight with the targets while minimizing the necessary earthwork. To best minimize potential siting conflicts, firing points and firing positions such as defilades should be sited simultaneously to determine what layout best maintains line-of-sight while minimizing potential environmental problems.

\section{Topography}

Topography is extremely important when siting a firing point, as line-ofsight from firing positions will dictate how high the target berms must be. An ideal condition would have both the firing points and the berms located on a relatively level area with the firing points on slightly lower elevations than the berm to minimize earthwork. Avoid siting firing points on crests of high hills, mesas, or ridges as these areas will be highly erodible. Firing points sited upslope of berms will require a greater height to minimize overshots.

Additionally, firing points should not be sited in or near floodplains as erosion from the firing points will potentially create water quality issues. Other surface waters should be avoided as well. Consideration should also be given for the access road to the firing point, as it should avoid any obstacles, such as surface water, that could significantly increase the construction cost of the range.

\section{Geology/Soils}

A thorough knowledge of the geologic and soil properties of any potential firing point site is required in choosing ideal locations. Important geologic information to gather at any potential site is the type and depth of bedrock material, depth of the water table, and locations of any karst formations.

At the site, a thorough investigation of soil properties is needed to ensure their suitability. If local soils do not possess desirable engineering properties, soil with desirable properties may have to be brought to the site. Erosion potential of the soil is also important because firing point soils should be as resistant to erosion as possible. Firing point soils should also be capable of supporting vegetation. Inadequate soils will be more prone to erosion and may require a layer of topsoil in order to promote growth. 


\section{Climate}

Knowledge of climatic factors such as precipitation events is useful in locating suitable firing point sites. An area that is prone to flooding or high runoff may not be suitable. Prevailing winds and average wind speed are also important due to the potential for dust generation from firing points. Firing points should not be place upwind from an area where dust can cause health or safety problems. Air quality impacts for fugitive dust generation from construction and usage may require permits. Temperature is important as well. Firing points located in areas with hot, dry summers may benefit from placement in a north-south direction to limit exposure of faces to the south. However, because the pit of the firing point is reinforced with a bumper and does not require vegetation, the front face of the firing point will benefit most from a northerly aspect.

\section{Water Resources}

Firing points should not be located near any bodies of surface water due to potential for high erosion and sediment transport. Firing points should not be placed in 100-year floodplains. Buffer zones should be established if firing points must be sited in proximity to water bodies. Nearby wetlands may require protection or construction of mitigated wetlands in another area. Drainage patterns in the watershed where the firing point will be sited should be assessed to minimize erosion potential. Further, firing points should not be sited in areas with high water tables since waterlogged soils can lead to damage or failure, and flooding of the firing pit can lead to training restrictions. Movement of excess water should be determined and it should be directed to flow into a suitable off-site location.

\section{Threatened/Endangered Species}

The presence of TES or critical habitat needs to be determined at each potential site. If TES are present in the vicinity, the first consideration should be to avoid constructing a firing point because special requirements may have to be met. Certain restrictions may be imposed if noise, dust, or other activities associated with the firing point interfere with TES.

The presence of critical habitat should be easier to overcome as these areas are easier to avoid due to their more permanent residence. If avoidance is not possible, other restrictions may be required, such as seasonal closure during reproduction. 


\section{Cultural Resources}

Potential sites should be thoroughly surveyed for the presence of culturally significant sites as NEPA 106 permits are required before construction.

\section{Vegetation}

The most important consideration for vegetation in siting a firing point is line-of-sight. If natural vegetation in the area interferes with line-of-sight, it will most likely continue to pose problems in the future. Areas where grasses and forbs can be planted and maintained are a more desirable alternative to woody vegetation. Burning the area to maintain line-of-sight is cost effective and fast. Areas where burning is restricted may not be the best choice because fires can be expected due to the nature of the activity and because of increased maintenance requirements without fires. The presence of riparian vegetation often indicates a nearby source of surface water and should be investigated to determine the potential for water quality degradation. Vegetation in potential areas should also be investigated to determine the presence of TES habitat and to assess the potential for revegetation once construction is completed. Vegetation can also be important in mitigating dust and noise, and naturally occurring vegetation should be assessed for their potential utilization around the proposed site.

Observing existing vegetation on potential sites is also an important assessment tool. Soils with thick vegetative cover are capable of supporting future plant growth, are more resilient to disturbance, and give a good indication of how well seeds will establish once any construction or disturbance is completed. Areas with sparse vegetation may require greater effort to support desired vegetation, such as importing suitable topsoil or selecting more adaptive vegetation when reseeding.

\section{Noise}

Firing points should not be sited in areas where noise propagation is a concern, such as near installation edges with high neighbor populations.

\section{Section 2: Design and Construction}

When constructing a firing point, the most important factor to consider is mitigation of the blast forces imposed on the firing point. Firing points often fail due to inadequate reinforcement. Ensuring the blast mat materials have been successfully used for similar types of weapons and training 
loads will decrease maintenance requirements and extend the life of the firing position.

\section{Materials}

Firing positions are most prone to degradation on the front face, where most of the blast forces are concentrated. Selection of the materials is very important in ensuring that the firing position will withstand training constraints. Subsurface material should consist of strong, flexible material that can support a blast mat and will not deteriorate or deform over time. The surface material should be very strong and comprised of material that will resist pulverization and subsequent entrainment as dust particles.

\section{Drainage}

Firing positions should be constructed such that the front face and surrounding area are well drained. The firing pit should not allow water to stand and may require drainage structures if placed in a low area or area with a high water table.

\section{Vegetation}

Vegetation should be maintained at all times to reduce erosion. Selection of appropriate species is extremely important to ensure adequate cover and can be obtained from a variety of sources, including VegSpec and the local NRCS office.

\section{Dust Control}

During construction, steps should be taken to minimize dust generation, such as applying palliatives to bare soil, maintaining vegetative cover, and halting construction on windy days. A blast mat or other cover should be used to protect the front face and surrounding area to reduce dust generation from blasts.

\section{Section 3: Operation and Maintenance}

Firing points generally require significant maintenance due to their intended usage. However, maintenance requirements can be reduced simply by ensuring that they are constructed properly and by addressing small problems before they become much larger. 


\section{Ruts}

Rutting in the firing pit should be smoothed out immediately to ensure proper usage is sustained. If drainage is a problem, subsurface drainage may be required to ensure training is sustained.

\section{Erosion}

Exposed soil needs to be kept at a minimum to reduce erosion. Reseeding affected areas is quick and cheap and often times will reduce the risk of erosion to firing point faces. If erosion control structures are used, periodic checking to ensure proper function will significantly reduce the potential for failure. Damage to blast mats or subsurface material should be fixed as soon as possible to avoid further damage and erosion of materials.

\section{Vegetation}

Maintaining vegetation on firing points is very important for reducing erosion of the slopes. Mowing will maximize basal cover and reduce fine fuel load. Line of sight should also be maintained at all time to minimize missed shots.

\section{Dust Control}

If substantial dust is generated from firing points, a dust palliative applied to the firing point face may provide a short term reduction in dust. Windbreaks should be maintained for this purpose and any problems with trees or other vegetation should be addressed as well.

\section{Section 4: Closure}

Closure of firing points will most likely occur when an entire range is closed. Blast mats and bumpers should be removed and recycled. If the firing pit is hardened, simply smoothing out the firing position is adequate. If the firing pit is improved, surface materials may require removal. If contamination from munitions is present, firing point soil will require remediation or disposal in a designated landfill. 


\section{Low-water Crossings}

\section{Checklist for Planning and Siting of Low-water Crossings}

․ Obtain topographic maps, soil maps, and aerial photographs of proposed crossing site.

口 Identify potential road routes that can avoid crossing the water.

If route must cross water, look for straight stream segments where the least flow occurs through field investigations or on hydrologic maps.

o Construction within or near a wetland or water body requires permitting $(404,401$, and other pertinent state and local permits).

- See DPW, Environmental Office, and ITAM Office

Ensure wetlands surrounding the site are minimal. The presence of wetlands greater than 1 acre will require delineation and permitting.

o Wetland delineation may be required.

- See Environmental Office

Determine if proposed site contains any threatened or endangered species or critical habitat. The presence of threatened and/ or endangered species may restrict the use of the crossing and the presence of critical habitat may restrict vegetation clearing.

o TES or critical habitat may require a Biological Assessment (BA), Environmental Impact Statement (EIS), and/ or Environmental Assessment (EA).

- See Environmental Office, TES Office, and ITAM Office

Determine if the proposed site contains any archaeological or other historic sites that may be damaged.

o Construction permits will require NEPA 106 documentation.

- See Environmental Office or Cultural Resources Manager

- Ensure crossing site is located in an area where the water body is relatively straight and flat and lacks nearby tributaries. Meandering streams, large drops in elevation, and tributaries can cause unpredictable and erratic flow and require extensive bed and bank protection and frequent maintenance.

口 Ensure road approach is less than 12 feet above streambed. If approach is greater than 12 feet the road cut may be too steep and require extensive erosion control. Also, ensure that the crossing will not provide a channel for movement of surface water into the stream, as this may create a point source. 
- Determine if crossing site has a high water table, shallow bedrock, or karst formations nearby. Water crossings near these areas may violate the Clean Water Act.

口 Determine soil properties of streambanks to determine erodibility, particle size, plasticity, permeability, and structural stability (found in the county soil survey). Inadequate soils will require extensive streambank stabilization.

a Ensure no excessive seepage occurs in the streambanks at the crossing site. Seeps may reduce the stability of the streambanks.

a Determine if the streambed contains stable materials (sand, pebbles, or rock). Streambeds comprised of silt are unstable and will require extensive streambed protection.

口 Look for bank undermining as this may require significant streambed protection to prevent structural damage to the crossing.

- Ensure that adequate vegetation is present on banks. The presence of fresh rill or gully erosion indicates inadequate vegetation and may require topsoil replacement and extensive erosion control.

a Determine high and low water levels. Simple crossings are not desirable if the water level fluctuates more than 6 inches during the year.

- Determine stream flow (i.e., perennial, intermittent, or ephemeral). Low-water crossings are best suited for intermittent and ephemeral streams. Simple LWCs can be used for perennial streams if they are slow flowing and no deeper than 6 inches.

口 Obtain all necessary permits. 


\section{Checklist for Operation and Maintenance of Low-water Crossings}

․ Conduct thorough and regular maintenance checks if the crossing is a permanent, high traffic route.

- Check crossing for potential maintenance problems after every significant storm event or every 6 months, which ever occurs first. Determine if crossing is functioning properly to support its intended use.

口 Check all associated drainage structures to ensure adequate operation and remove potential obstructions.

口 Determine if adjacent road runoff is directly entering stream. If road runoff is entering stream, the road may be damaged and water quality will be reduced. Water bays and/ or divergents may be required to ensure water quality.

a Ensure road cut slopes are stable.

口 Determine if vegetation and/ or erosion control structures on cut slopes are adequate and functioning.

- Reseed areas if vegetation is sparse or otherwise inadequate, and mulch if necessary.

- Repair or replace riprap or other erosion control structures as needed.

口 Determine if deposition (logs, rocks, silt) is occurring on or near the crossing. If deposition is present, the deposited material will require removal with minimal disturbance to the stream.

a Determine if a plunge pool has appeared near the downstream side of the crossing. Plunge pools require immediate repair of shoulders or other undercutting control structures to prevent structural failure of the crossing.

- Determine if any other signs of undermining of the banks, shoulders, or other structures are present. If undermining is present, use measures to reduce the erosion and prevent potential failure of the crossing.

口 Ensure stream embankment shoulders are in good shape. Riprap slopes should be smooth and gentle. If present, gabion cells should be intact and not torn. Torn cells will require repair.

口 Observe banks both upstream and downstream for signs of scouring. If scouring is present, additional erosion control may be necessary to prevent potential failure of the crossing. Determine if any threatened or endangered species are impacted in or around the crossing. The presence of TES may require unimpeded movement of organisms upstream and downstream from the crossing. If the crossing impedes movement, the problem will need to be remedied. 


\section{Section 1: Planning and Siting}

When planning and siting a low-water crossing (LWC), the first consideration should be to determine if a crossing is necessary. If it is possible to avoid the stream, this would bypass numerous potential environmentally related problems. Even if the low water crossing can be replaced with a culvert crossing, permitting is still required. When a crossing is required, the most critical step is locating an ideal crossing site that will reduce erosional processes and minimize impacts on the stream itself. Selecting an optimal location will significantly reduce maintenance costs and prolong the life of the crossing. As the intensity of use increases, greater attention needs to be paid to the factors discussed in the following paragraphs.

\section{Topography}

Gross site topography is very important when selecting an appropriate crossing location. Knowing the size and average slope of the watershed will aid in determining suitable locations and give a general idea of what types of flow to expect. Avoiding stream areas with sharp changes in slope, numerous turns, and emptying tributaries will significantly reduce the potential for erosion and subsequent failure of the crossing.

Topographic analysis of potential sites is fundamental in choosing the right location. The width and depth of the stream channel are paramount as the best LWCs are in wide, shallow streams. Additionally, the slope of the road approach and depth to the stream bed should be taken into consideration as any steep slopes will have to be excavated and will increase erosion of the banks. Ideal locations are where the road approach is less than 12 feet above the stream bed. Areas that will potentially channel waters through the crossing and into the stream should be avoided.

\section{Geology/Soils}

A thorough knowledge of the geologic and soil properties of any potential LWC site is required in choosing ideal locations. Important geologic information to gather at any potential site is the type and depth to bedrock material, depth of the water table, and identification of karst formations. Determining the drainage capacity of major soils in the watershed will provide further information regarding the types of flow to expect in the stream. 
At the site, a thorough investigation of properties of the bank and channel materials is needed to ensure their suitability. Bank soils that are highly erodible, lack structural stability, have a small particle size, have low plasticity, and/ or have low permeability should be avoided. Excessive seepage should be avoided. Bed materials should be as large as possible (silt is least stable, gravel is most stable) as highly erodible materials may have to be excavated and replaced with stable substrates. Observing the stability of bank and stream bed materials both upstream and downstream from the site will also help in determining the suitability of potential sites. The presence of undermining is a good indicator that the soils are not suitable for constructing a crossing as they are easily eroded by the stream. Areas with sparse vegetation may require greater effort to support desired vegetation, such as importing suitable topsoil material.

\section{Climate}

Knowledge of climatic factors such as precipitation events is useful in locating suitable sites. If the area is subject to frequent high intensity storms, a LWC may not be the best option. If high intensity storms or the majority of annual precipitation occur in one season or fraction of the year, seasonal closure of the crossing may be required. Temperatures are important as well. Freezing water is not only a safety issue, but can cause significant problems for LWCs, such as ponding upstream and subsequent undercutting as ice builds up on the crossing.

\section{Hydrology}

Hydrologic properties of the stream are usually studied in detail prior to construction of crossings, but a general assessment during siting can further aid in determining suitable crossing locations. The main properties that will be useful are peak discharge rate, flow depth, and flow velocity. Low- and high-water levels should be determined. Additional considerations should be given to flow restrictions, such as the presence of boulders, logjams, and other debris, vegetation density of the banks and bed, level of meandering upstream and downstream, and cross sectional area upstream and downstream, as these factors will all affect depth and velocity of the stream and subsequent erosion. Generally, intermittent and ephemeral (seasonal flow or flow only after storms) are best used for unimproved crossings and perennial streams usually require more expensive vented fords or low bridges unless they are very shallow (depth less than 6 inches) and have low water velocity. 


\section{Threatened/Endangered Species}

The presence of TES or critical habitat needs to be determined at each potential site. If TES are present in the stream or streambed or in close proximity to the site, the first consideration should be to avoid constructing a crossing as special requirements will have to be met. Certain restrictions such as ensuring the crossing does not impede movement and avoiding any changes in velocity or depth of the stream, turbidity fluctuations, rates of sedimentation, or bed substrate material may have to be implemented and may require significant increases in construction costs. The crossing may have to be modified by constructing special vented fords to overcome these restrictions.

The presence of critical habitat should be easier to overcome if the areas are avoided. If avoidance is not possible, other restrictions may be required, such as seasonal closure and additional permitting restrictions. For instance, if the crossing is built in an area of nesting trees for an endangered migratory bird, the crossing may have to be closed during the breeding season if traffic is found to interfere with reproduction, or certain trees may be restricted from cutting if they are critical to the nesting success of the bird.

\section{Vegetation}

Existing vegetation can be another good tool for determining suitability of potential LWC sites. If the banks support dense vegetation, they are probably capable of supporting vegetation during and after construction, which is necessary to reduce erosion and potential damage to the crossing and/ or stream. Observing existing vegetation on potential sites is also an important assessment tool. Soils with thick vegetative cover are capable of supporting future plant growth, are more resilient to disturbance, and indicate how well seeds will establish once any construction or disturbance is completed. Areas with sparse vegetation may require greater effort to support desired vegetation, such as importing suitable topsoil material or selecting more adaptive vegetation when reseeding. Another consideration should be the type of vegetation. Large trees are potential logjams and areas with considerable amounts of dead or dying trees upstream or downstream should be avoided. Wetland areas on approaches may require mitigation and should be avoided. 


\section{Section 2: Design and Construction}

When constructing a LWC, two key factors need to be considered. First, erosion from the construction site needs to be minimized and runoff should be diverted through a vegetated area or otherwise filtered before entering the stream. Second, all construction activities should occur during low flow when the possibility of intense storms is reduced and interference with spawning or other activities of stream inhabitants is minimized. From an environmental standpoint, crossings must not restrict channel flow, back water onto adjacent property, increase sediment loads upstream or downstream, or interfere with natural movement of aquatic organisms. Although most of the design and construction will be performed by engineering contractors, some areas of this process can be enhanced by making some preliminary decisions regarding environmental, maintenance, and cost requirements.

\section{Materials}

Depending on the type of crossing being constructed, certain materials may pose environmental threats and should be locally obtained whenever possible. Fill dirt, sand, and gravel and erosion control materials such as straw and mulch could contain seeds of invasive plant species, insect pests, bacterial or fungal pathogens, or other harmful organisms. If materials must be obtained from outside sources, care should be taken to ensure safe products are utilized, such as certified weed-free mulch. Adequate safety of products can be ensured simply by carefully wording statements of work.

\section{Streambank Stabilization}

Any construction activities that disturb the streambank may increase the risk of erosion. Designing crossings that incorporate streambank stabilization procedures can significantly reduce streambank erosion. Many different methods have been developed for different circumstances (e.g., riprap, gabions, bioengineering) and choosing the right option or combination of options depends on many factors (see Appendix B for more information).

\section{Road Cut Stabilization}

Designing the entrances to the crossing will require lowering the road to meet the crossing. If the cut is significantly steeper than the adjacent area, erosion can be a severe problem and it is recommended that road approaches be no steeper than 6 horizontal to 1 vertical and ideally 10 to 1 
with side slopes no steeper than 2:1 vertical for soil and 1.5:1 vertical for rock cuts. The cut can be widened to allow gradual tapering from the natural slope but increases cost and the footprint of the crossing on the stream. Erosion control options are similar to streambank stabilization and include riprap, geotextiles, and bioengineering. Road entrances to crossings should be designed to protect crossings from upslope erosion and ditches should be directed away from the crossing to a suitable stable area.

\section{Stream Bed Stabilization}

Prevention of undermining of the crossing is the most important aspect of erosion control for this type of structure because this process can destroy the crossing if not addressed. For unimproved fords or semi-permanent crossings, riprap is usually the material used. Unsurfaced crossings are not recommended as they usually result in significant alterations of stream hydrology and once eroded, require greater cost to fix. Plunge pools can form downstream and increase undermining unless shoulders or aprons are adequately constructed. Whether recommended or not, shoulders should be used in all crossings to reduce maintenance and erosion. Permanent LWCs usually require concrete aprons and cutoff walls on both the upstream and downstream sides to effectively reduce undermining. Shoulders should start at a height equal to the top of the crossing surface and a depth at least as deep as the base of the crossing surface. Shoulder material should be extended in both directions from the crossing at a slope no greater than 4:1. Dumped riprap is the best material for shoulders on most LWCs as it is cheap, provides excellent stability, and fills in quickly from siltation, which reduces sediments and provides a suitable substrate for vegetation establishment. An alternative to dumped riprap is rock gabions that are flexible and thus more resistant to undermining. However, the wire or fabric baskets can break, increasing maintenance costs to replace them.

All crossings should be hardened in some way to allow unimpeded movement of fish and other aquatic organisms. If passage of aquatic organisms is required, a crossing that resembles the natural stream bed will be necessary and can be as simple as a crossing sunk into the existing bed that is roughened or uses materials already present. The finished top surface of all crossings should not be higher than the original stream bed. Water velocities should not increase. If the water is too deep for a sunken crossing, or if water quality concerns require keeping vehicles out of water to reduce 
water quality degradation (from dirt, spills, and leaks), a vented ford with box culverts or low bridge may be needed to address these problems.

\section{Construction Site Management}

Construction activities offer the highest potential for erosion and great care should be taken to minimize this. Bare soil at the site should be seeded immediately once construction activities on it are reduced. Permanent seeding should consist of native vegetation suited for that site and should be certified to prevent the introduction of invasive species. If rapid erosion control is necessary, cover crops of short-lived species can be added to native seed mixes to stabilize soil until adequate native vegetation is established. Silt fences or other practices should be used to divert runoff into a safe area to avoid direct movement into the stream. Additionally, heavy equipment should not operate in the channel unless absolutely necessary to reduce suspended sediments and pollution from leaks, spills, and exhaust.

\section{Section 3: Operation and Maintenance}

Low water crossings are designed to be low-maintenance structures. However, periodic checks, especially after major storms, are necessary to remove any debris and address any erosion problems that may occur before they reach a level that jeopardizes the structure. The materials used to construct the LWC primarily dictate the level of maintenance, as concrete structures require the least maintenance and simple rock fords require the most.

\section{Banks}

Banks and road cuts need to be checked to ensure adequate erosion control is present (e.g., vegetation, rock, etc.). If any new erosion is occurring, fixing the problem as soon as possible is necessary to prevent significant harm to the crossing and/ or stream and reduce costs from reapplying fill materials to eroded areas. Scouring from the stream and gullies from bank and road runoff are the two most common erosional processes that will need attention throughout the life of the crossing.

\section{Bed}

Undermining is the most costly maintenance problem as it can easily compromise the structural integrity of the crossing. Any evidence of un- 
dermining should be remedied as soon as possible and will require filling any cavities created by erosion and re-creating shoulders to the desired widths and depths. The presence of a plunge pool near the downstream edge of the crossing will require immediate attention. Additionally, any deposition on or around the crossing needs to be removed, as this may alter the flow of the stream and/ or create barriers for aquatic organisms.

\section{Section 4: Closure}

Closure of low water crossings depends largely on the status of the accompanying road. Closure of unimproved LWCs is most easily accomplished and consists of smoothing out the road cut to prevent erosion, providing adequate vegetative cover to the road cut and streambank, and letting natural processes of vegetation succession and stream flow take over. Closure of improved crossings may require removal of concrete or other permanent structures that will impede natural processes before the above mentioned tasks can be completed. Any construction activities will require additional permits. 


\section{Roads and Trails}

\section{Checklist for Planning and Siting of Roads and Trails}

- Obtain topographic maps, soil maps, and aerial photographs of proposed roadway site.

- Ensure roadway location is sited on geomorphically stable or less degradable slopes.

- Ensure roadway location has good subgrade material, gentle slopes and no disruption of natural drainage patterns.

- Identify areas to be avoided by the roadway, such as, wetlands, endangered species habitat, steep or rocky slopes, areas with high water tables, or areas with erosive soils.

- Wetland delineation may be required.

- See Environmental Office

- Ensure that roadway is not aligned perpendicular to the contours of steep slopes

- Determine total elevation difference between control points, such as, high and low points, intersections, and training sites, bivouac areas, or firing points.

․ Multiply each elevation difference by 12.5 to determine the minimum road length required between the control points (calculation assumes road construction at an average grade of eight percent).

- Conduct a foot survey of proposed roadway to identify features not visible on topographic maps or aerial photographs (work from the upper slopes to the lower slopes for best overview of the site).

- Identify potential buffer strips, ephemeral or perennial channels, springs, bogs, outcrops and other features not visible on topographic maps.

Route roadways sections above wet areas, whenever possible. Acquire permits for any roadway sections that must be routed through wetlands and any other permits that may be required for TES and cultural resources.

- TES or critical habitat may require a Biological Assessment (BA), Environmental Impact Statement (EIS), and/ or Environmental Assessment (EA).

- See Environmental Office, TES Office, and ITAM Office o Construction permits will require NEPA 106 documentation.

- See Environmental Office or Cultural Resources Manager Make ephemeral or perennial channel crossings at right angles to the flow of water.

Use culvert crossings, low-water crossings or bridges over ephemeral or perennial channels to avoid disturbance to aquatic ecosystems. 
Site roadways away from erodible soils, steep slopes, bluff edges, river banks, natural drainageways, lakes, ponds, springs, windy areas, high water tables, floodplains and wetlands.

- Costs of roadway rehabilitation, maintenance and construction will increase in steep terrain because of shallow soils, rock outcroppings on the surface and the need for earthmoving in cut and fill sections.

․ Site roadways away from South and West facing aspects since they will be more susceptible to erosion due to solar intensity.

- Obtain total annual rainfall data, rainfall intensity and duration data, average storm/ flood frequency, and seasonal temperature extremes for use in the hydraulic design of drainage control structures, such as, diversions, ditches and culverts.

口 Obtain seed mixtures tested for critical areas or roadsides for the locality of the roadway.

- Ensure surface and subsurface moisture control is in place in areas that experience freezing conditions and a high frequency of freezethaw cycles.

- Consider the training impacts on the roadway or trails to be constructed. Road width, subgrade material and the need for dust control will depend heavily on the types of vehicles and training activities scheduled.

- Ensure that foundations under the roadway, subgrades and base courses have adequate strength for the weight of vehicles, good compaction characteristics, adequate drainage, frost heave resistance and limited expansion or compression characteristics.

a Collect and analyze soil samples along the proposed roadway site, since soil type and texture influence compaction, infiltration properties, resistance to erosion, and vegetative suitability.

- County Soil Surveys can provide information about soils prevalent on most installations.

Check with installation foresters for necessary approval or assistance with harvesting the timber if woody vegetation or trees need to be cleared to construct the roadway,

․ Ensure proper drainage design that channels runoff to desired areas. Poor drainage can lead to erosion and contaminate nearby surface waters. 


\section{Checklist for Operation and Maintenance of Roads and Trails}

- Routinely inspect road and trail surfaces, ditches, culverts, and erosion control measures, especially following periods of high runoff.

a Prioritize road and trail maintenance based on safety, erosion potential, training requirements and traffic volume

口 Prepare a list of required materials and check with suppliers regarding availability, price and delivery schedules if maintenance measures are needed.

口 Plan major maintenance of roads during milder, drier seasons of the year.

- Clean out accumulated debris in ditches, sediment traps and culverts on a regular basis to prevent plugging, flooding or washouts.

口 Determine if vegetation and/or erosion control structures along road banks are adequate and functioning.

- Reseed if vegetation is sparse or otherwise inadequate, and mulch if necessary.

- Reshape ditch, backslope, and foreslope to bring up to subgrade and grade.

Perform light blading to prevent or remove irregularities and keep road surfaces free of potholes, ruts corrugations and rills.

- Maintain a proper crown on road surfaces to prevent water from remaining on the surface and saturating the soils. Use graders or drags to maintain crown at regular intervals.

a Control dust on road surfaces through the application of water, soil stabilizers, or dust palliatives. 


\section{Section 1: Planning and Siting}

When planning and siting unimproved roads and trails on ranges, make sure that the roadways are absolutely necessary to complete mission requirements. Consider the training impacts on proposed roads and trails. Road width, subgrade material, and the need for dust control will depend on the types of vehicles and training activities scheduled. Identify areas that should be avoided, such as, wetlands, sensitive areas, threatened and endangered species habitats, steep slopes, areas with erosive soils, and areas where the water table is close to the surface.

\section{Topography}

Gross site topography is very important when selecting appropriate locations for roads and trails. Knowing the size and average slope of the watershed will aid in determining suitable locations and give a general idea of what types of flow to expect. Avoiding areas with sharp changes in slope, numerous turns, and nearby tributaries will significantly reduce the potential for erosion.

Topographic analysis is fundamental in choosing the right location. A roadside ditch can be considered an ephemeral stream component of the watershed, as the discharge from a drainage ditch typically enters a perennial stream. An estimate of the actual drainage area of any point along a ditch should be determined with a topographic map and a quick field survey. Usually, the drainage basin of interest will be made up of the road surface, the ditch and the adjacent slopes feeding runoff within the watershed.

\section{Geology/Soils}

A thorough knowledge of the geologic and soil properties of proposed roads and trails is required in choosing ideal locations. Important geologic information to gather at any potential site is the type of subgrade material, depth of the water table, and locating any karst formations. Coarsegrained materials usually make the best subgrade or subbase materials. The fine-grained soils, both silts and clays, make very poor subgrade or subbase materials. Clays are the worst materials to use.

A thorough investigation of properties of the subgrade and subbase materials is needed to ensure their suitability. Soils that are highly erodible, 
lack structural stability, have a small particle size, have low plasticity, and/ or have low permeability should be avoided. Road surface materials should be as large as possible (aggregates are the most stable) and should be graded to limit the quantity of loose aggregate and to control fines. Grading also improves drainage, shear strength, stability, and surface texture.

\section{Climate}

Knowledge of climatic factors such as average annual precipitation is useful for planning suitable roads and trails. If the area is subject to frequent high intensity storms, roads should be designed to allow adequate runoff. If high intensity storms or the majority of annual precipitation occur in a single season or fraction of the year, drainage designs to handle increased runoff or seasonal closure of roads and trails may be required. Temperatures are important as well. Freeze-thaw factors can affect the stability of the subgrade or subbase materials, as well as, the stability of road banks and ditches.

\section{Hydrology}

A general assessment of hydrologic properties of the watershed will aid in determining suitable road locations. The main properties that will be useful are peak runoff, sedimentation rates, and areas of deposition. An assessment of roads and trails contributions to runoff and sediments should be made, since the placement of roads within an area of high runoff can significantly contribute to non-point source pollution across an installation. Avoid siting any road section where the water table is less than 24 inches from the surface. Roadbed construction in wet areas often results in costly and labor intensive maintenance efforts. Movement of excess water should be determined and it should be directed to flow into a suitable off-site location.

\section{Threatened/Endangered Species}

The presence of threatened or endangered species (TES) or critical habitat needs to be determined along planned roadways. If TES are present, the first consideration should be to avoid constructing a road through the area so critical habitats can be avoided. Certain restrictions such as ensuring the road or vehicle traffic will not adversely affect TES habitats. 
The presence of critical habitat should be easier to overcome as these areas may be easier to avoid due to their more permanent residence. If avoidance is not possible, other restrictions may be required, such as seasonal closure. For instance, if the road is built in an area of nesting trees for an endangered migratory bird, the road may have to be closed to traffic during the breeding season.

\section{Vegetation}

Observing existing vegetation on potential sites is also an important assessment tool. Soils with thick vegetative cover are capable of supporting future plant growth, are more resilient to disturbance, and give a good indication of how well seeds will establish once any construction or disturbance is completed. Areas with sparse vegetation may require greater effort to support desired vegetation, such as importing suitable topsoil material or the selection of more adaptive vegetation when reseeding. Wetland areas on approaches may require mitigation and should be avoided.

\section{Section 2: Design and Construction}

Field observations of roads and trails at several installations have shown that the current standard designs are adequate and appropriate. Dust from course roads, on the other hand, can lead to numerous significant problems such as visibility reduction, increased vehicle maintenance, increased road maintenance, environmental degradation, increased sedimentation, air pollution and associated health risks. Road deterioration can increase because of loss of fines (i.e., $<0.075 \mathrm{~mm}$ ), since they act as road surface binders. Loss of fines from road and trail surfaces can cause road safety issues, increased vehicle maintenance, and increased road maintenance. The use of dust suppressants has been shown to lower road maintenance requirements, vehicle maintenance costs, and mitigate environmental and health impacts associated with road dust.

\section{Materials}

Roadway materials should be obtained from local sources, when possible, as these materials will lessen the chances for introduction of invasive plant species. Material gradations include crushed stone, gravel, crushed gravel, sand and slag, as well as, filler, binders, and chemical dust palliatives. Pre- 
pare a list of required materials and check with suppliers regarding availability, price and delivery schedules

\section{Erosion and Sediment Control}

Provide early runoff and sediment control such as slope diversions or crest cuts and sediment traps to prevent sedimentation from becoming a problem.

\section{Vegetation}

Consider the design width of the roadbed and the drainage ditches when clearing vegetation for right-of-way. Some trees or woody growth may have to be cleared from heavily forested areas, however, consult with the installation forester and environmental staff before cutting trees. Clear a slightly wider area around curves to improve visibility. In poorly drained areas, thinning or clearing extra vegetation will reduce canopy cover and permit drying of problem wet spots. Make sure no organic material is incorporated into fill materials. As organic matter decomposes, fill materials will become unstable.

\section{Drainage Structures}

Before surfacing the road or trail, inspect the drainage structures (rolling dips, ditches, and culverts) for proper installation, siting and sizing for expected surface water runoff. Check to see that the crown and insloping and outsloping of the roadway surface is adequate to handle expected runoff. Make corrections during construction if the work is not up to specifications or designs.

\section{Construction Site Management}

Construction activities offer the highest potential for erosion. Bare soil on roadbanks should be seeded immediately once construction activities on it are completed. Permanent seeding should consist of native vegetation suited for that site and should be certified to prevent the introduction of invasive species. 


\section{Section 3: Operation and Maintenance}

Traffic volume on roads should be appropriate to the surface materials and subgrade of the roadway. Routine maintenance activities include inspections, maintenance and repair of all road surfaces and drainage systems, stockpiling of materials for maintenance and repair, dust control, and other work necessary to keep roads and trails to conform with original surfaces as designed. When repair, construction or rehabilitation is extensive or involves a long section of the roadway, establish a work schedule that will allow no more than 500 feet of roadway to be worked on in succession to ensure the road will not require closure for extended periods of time. Aggregate surfacing and seeding are best completed while the soil is still freshly disturbed, so do not delay surfacing or seeding after repairs.

\section{Vegetation}

Maintain vigorous vegetative cover on road banks and along trails to include shoulders, drainage ditches, adjacent slopes, and runoff outlet areas. Periodically mow or cut back vegetation that encroaches on the roadway, prevents surface water from flowing freely to drainage structures, or shades moist areas. Limit the use of herbicides as runoff may result in contamination of streams or ponds. Inspect vegetation seasonally to determine the need for supplementary or modified seed, fertilizer or mulch treatments.

\section{General Maintenance Considerations}

Inspect road surfaces on a regularly scheduled basis to facilitate early detection of surface defects before failures occur. Surfaces inspected on a regular basis are less likely to develop major problems and will allow for spot repairs when needed. Identify the source of the problem early in order to correct the problem in the most cost-effective manner. Inspect drainage structures both during and immediately following rain events to determine their effectiveness and to identify potential problems. Culverts, inlets, outlets and check dams should be inspected for erosion and debris accumulation. Ditch bottoms should be inspected for incision and deposition, knick-point migrations and gully development. The cause of ponded water or roadway flooding should be identified and corrected. 


\section{Section 4: Closure}

Closure of roads and trails may be necessary when erosion control structures have failed or when the structure is no longer needed. Surface materials should be removed and recycled to allow natural vegetation establishment. Erosion control structures should be removed and graded to reestablish natural movement of surface water. All exposed soils should be reseeded with native vegetation. 


\section{Landing Zones}

\section{Checklist for Planning and Siting of Landing Zones}

- Obtain topographic maps, soil maps and aerial photographs of proposed landing site.

- Identify potential landing zone sites that can avoid crossing water, floodplains, or shallow subsurface water.

Ensure landing zone is sited on geomorphically stable or less degradable slopes.

- Ensure landing zone location has good subgrade material, gentle slopes and no disruption of natural drainage patterns.

- Identify areas to be avoided by the landing zone, such as, wetlands, endangered species habitat, steep or rocky slopes, areas with high water tables, or areas with erosive soils.

o Wetland delineation may be required.

- See Environmental Office

- Ensure that landing zone is not aligned perpendicular to the contours of steep slopes

a Conduct a foot survey of proposed site to identify features not visible on topographic maps or aerial photographs (work from the upper slopes to the lower slopes for best overview of the site).

口 Identify potential buffer strips, ephemeral or perennial channels, springs, bogs, outcrops and other features not visible on topographic maps.

口 Site landing zone above wet areas, whenever possible.

Acquire permits for any roadway sections that must be routed through wetlands and any other permits that may be required for TES and cultural resources.

o TES or critical habitat may require a Biological Assessment (BA), Environmental Impact Statement (EIS), and/ or Environmental Assessment (EA).

- See Environmental Office, TES Office, and ITAM Office

o Construction permits will require NEPA 106 documentation.

- See Environmental Office or Cultural Resources Manager

口 Site landing zone away from erodible soils, steep slopes, bluff edges, river banks, natural drainageways, lakes, ponds, springs, windy areas, high water tables, floodplains and wetlands. 
- Costs of landing zone rehabilitation, maintenance and construction will increase in steep terrain because of shallow soils, rock outcroppings on the surface and the need for earthmoving in cut and fill sections.

- Site landing zone away from South and West facing aspects since they will be more susceptible to erosion due to solar intensity.

口 Obtain total annual rainfall data, rainfall intensity and duration data, average storm/flood frequency, and seasonal temperature extremes for use in the hydraulic design of drainage control structures, such as, diversions, ditches and culverts.

- Obtain seed mixtures tested for critical areas or roadsides for the locality of the landing zone.

- Ensure surface and subsurface moisture control is in place in areas that experience freezing conditions and a high frequency of freezethaw cycles.

- Consider the training impacts on the landing zone to be constructed. Width, subgrade material and the need for dust control will depend heavily on the types of vehicles and training activities scheduled.

- Ensure that foundations under the landing zone, subgrades and base courses have adequate strength for the weight of vehicles, good compaction characteristics, adequate drainage, frost heave resistance and limited expansion or compression characteristics.

- Collect and analyze soil samples along the proposed site, since soil type and texture influence compaction, infiltration properties, resistance to erosion, and vegetative suitability.

口 County Soil Surveys can provide information about soils prevalent on most installations.

口 Check with installation foresters for necessary approval or assistance with harvesting the timber if woody vegetation or trees need to be cleared to construct the landing zone. 


\section{Checklist for Operation and Maintenance of Landing Zones}

- Routinely inspect surfaces, ditches, and erosion control measures, especially following periods of high runoff.

Prioritize maintenance based on safety, erosion potential, training requirements and traffic volume.

- Prepare a list of required materials and check with suppliers regarding availability, price and delivery schedules if maintenance measures are needed.

a Plan major maintenance of landing zones during milder, drier seasons of the year.

- Clean out accumulated debris in ditches, sediment traps and culverts on a regular basis to prevent plugging, flooding or washouts.

口 Determine if vegetation and/or erosion control structures along landing zone is adequate and functioning.

口 Reseed if vegetation is sparse or otherwise inadequate, and mulch if necessary.

- Reshape ditch, backslope, and foreslope to bring up to subgrade and grade.

口 Perform light blading to prevent or remove irregularities and keep surfaces free of potholes, ruts corrugations and rills.

口 Maintain a proper crown on landing zones to prevent water from remaining on the surface and saturating the soils. Use graders or drags at regular intervals to maintain crown.

- Control dust on and around landing zones through the application of water, soil stabilizers, or dust palliatives. 


\section{Section 1: Planning and Siting}

When planning and siting landing zones on ranges, make sure that the landing zones are necessary to complete mission requirements. Consider the training impacts on proposed landing zones. Width, subgrade material and the need for dust control will depend on the types of vehicles and training activities scheduled. Identify areas that should be avoided, such as, wetlands, sensitive areas, threatened and endangered species habitats, steep slopes, areas with erosive soils, and areas where the water table is close to the surface.

\section{Topography}

Making a general overview of site topography is very important when selecting appropriate locations for landing zones and should be as flat as possible. Knowing the size and average slope of the watershed will aid in determining suitable locations and give a general idea of what types of flow to expect. Avoiding areas with sharp changes in slope and surface water will significantly reduce the potential for erosion.

Topographic analysis is fundamental in choosing the right location. A drainage ditch can be considered an ephemeral stream component of the watershed, as the discharge from a drainage ditch typically enters a perennial stream. An estimate of the actual drainage area of any point along a ditch should be determined with a topographic map and a quick field survey. Usually, the drainage basin of interest will be made up of the landing surface, the ditch and the adjacent slopes feeding runoff within the watershed.

\section{Geology/Soils}

A thorough knowledge of the geologic and soil properties of proposed landing zone sites is required in choosing ideal locations. Important geologic information to gather at any potential site is the type of subgrade material, depth of the water table, and locating any karst formations. Coarsegrained materials usually make the best subgrade or subbase materials. The fine-grained soils, both silts and clays, make very poor subgrade or subbase materials. When selecting soils, clays are the worst materials to use. 
A thorough investigation of soil physical properties of the subgrade and subbase materials is needed to ensure their suitability. Soils that are highly erodible, lack structural stability, have a small particle size, have low plasticity, and/ or have low permeability should be avoided. Landing surface materials should be as large as possible, up to a diameter of 2 inches (aggregates are most stable), and should be graded to limit the quantity of loose aggregate and to control fines. Grading also improves drainage, shear strength, stability and surface texture.

\section{Climate}

Knowledge of climatic factors such as average annual precipitation is useful for planning suitable landing zones. If the area is subject to frequent high intensity storms, landing zones should be designed to allow adequate runoff. If high intensity storms or the majority of annual precipitation occur in one season or fraction of the year, seasonal closure may be required. Temperatures are important as well. Freeze-thaw factors can affect the stability of the subgrade or subbase materials, as well as, the stability of banks and ditches.

\section{Hydrology}

A general assessment of hydrologic properties of the watershed will aid in determining suitable landing zone locations. The main properties that will be useful are peak runoff, sedimentation rates, and areas of deposition. An assessment of landing zone contributions to runoff and sediments should be made, since the placement of landing zones within an area of high runoff can significantly contribute to non-point source pollution across an installation. Avoid siting any landing zone where the water table is less than 24 inches from the surface. Construction of landing zones in wet areas often results in costly and labor intensive maintenance efforts. Movement of excess water should be determined and it should be directed to flow into a suitable off-site location.

\section{Threatened/Endangered Species}

The presence of threatened or endangered species (TES) or critical habitat needs to be determined around planned landing zones. If TES are present, the first consideration should be to avoid constructing a landing zone in the area so critical habitats can be avoided. Certain restrictions may be required such as ensuring that training activities will not adversely affect 
TES habitats. The presence of critical habitat should be easier to overcome as these areas may be easier to avoid due to their more permanent residence. If avoidance is not possible, other restrictions may be required, such as seasonal closure. For instance, if the landing zone is built near an area of nesting trees for an endangered migratory bird, it may have to be closed to traffic during the breeding season.

\section{Vegetation}

Observing existing vegetation on potential sites is also an important assessment tool. Soils with thick vegetative cover are capable of supporting future plant growth, are more resilient to disturbance, and give a good indication of how well seeds will establish once any construction or disturbance is completed. Areas with sparse vegetation may require greater effort to support desired vegetation, such as importing suitable topsoil material or the selection of more adaptive vegetation when reseeding. Wetland areas may require mitigation and should be avoided.

\section{Section 2: Design and Construction}

Field observations of landing zones at several installations have shown that the current standard designs are adequate and appropriate. Dust from landing zones, on the other hand, can lead to numerous significant problems such as visibility reduction, increased vehicle maintenance, increased surface maintenance, environmental degradation, increased sedimentation, air pollution and associated health risks. Landing zone deterioration can increase because of loss of fines (i.e., $<0.075 \mathrm{~mm}$ ), since they act as surface binders. This can cause safety issues, increased vehicle maintenance, and increased landing zone maintenance. The use of dust suppressants has been shown to lower surface maintenance requirements, vehicle maintenance costs, and mitigate environmental and health impacts associated with dust.

\section{Materials}

Landing zone materials should be obtained from local sources, when possible, as these materials will lessen the chances for introduction of invasive plant species. Material gradations include crushed stone, gravel, crushed gravel, sand and slag, as well as, filler, binders, and chemical dust palliatives. Prepare a list of required materials and check with suppliers regarding availability, price and delivery schedules 


\section{Erosion and Sediment Control}

During construction, provide early runoff and sediment control such as slope diversions or crest cuts and sediment traps to prevent sedimentation from becoming a problem.

\section{Vegetation}

Consider the design width of the landing zone and the drainage ditches when clearing vegetation for right-of-way. Some trees or woody growth may have to be cleared from heavily forested areas, however, consult with the installation forester and environmental staff before cutting trees. In poorly drained areas, thinning or clearing extra vegetation will reduce canopy cover and permit drying of problem wet spots. Make sure no organic material is incorporated into fill materials. As organic matter decomposes, fill materials will become unstable.

\section{Drainage Structures}

Before surfacing the landing zone, inspect the drainage structures (rolling dips, ditches, and culverts) for proper installation. Check to see that the crown and insloping and outsloping of the surface is adequate to handle expected runoff. Make corrections during construction if the work is not up to specifications or designs.

\section{Construction Site Management}

Construction activities offer the highest potential for erosion. Bare soil should be seeded immediately once construction activities on it are completed. Permanent seeding should consist of native vegetation suited for that site and should be certified to prevent the introduction of invasive species.

\section{Section 3: Operation and Maintenance}

Traffic volume on landing zones should be appropriate to the surface materials and subgrade of the landing zone. Routine maintenance activities include inspections, maintenance and repair of all surfaces and drainage systems, stockpiling of materials for maintenance and repair, dust control, and other work necessary conform with original surfaces as designed. Aggregate surfacing and seeding are best completed while the soil is still freshly disturbed, so do not delay surfacing or seeding after repairs. 


\section{Vegetation}

Maintain vigorous vegetative cover on shoulders, drainage ditches, adjacent slopes, and runoff outlet areas. Periodically mow or cut back vegetation that encroaches on the landing zone, prevents surface water from flowing freely to drainage structures, or shades moist areas. Limit the use of herbicides as runoff may result in contamination of streams or ponds. Inspect vegetation seasonally to determine the need for supplementary or modified seed, fertilizer or mulch treatments.

\section{General Maintenance Considerations}

Inspect landing zone surfaces on a regularly scheduled basis to facilitate early detection of surface defects before failures occur. Surfaces inspected on a regular basis are less likely to develop major problems and will allow for spot repairs when needed. Identify the source of the problem early in order to correct the problem in the most cost-effective manner. Inspect drainage structures both during and immediately following rain events to determine their effectiveness and to identify potential problems. Culverts, inlets, outlets and check dams should be inspected for erosion and debris accumulation. Ditch bottoms should be inspected for incision and deposition, knick-point migrations and gully development. The cause of ponded water or surface flooding should be identified and corrected.

\section{Section 4: Closure}

Closure of landing zones may be necessary when erosion control structures have failed or when the structure is no longer needed. Surface materials should be removed and recycled to allow natural vegetation establishment. Erosion control structures should be removed and graded to reestablish natural movement of surface water. All exposed soils should be reseeded with native vegetation. 


\section{Impact Areas}

Impact areas should already be located in a centralized location on the installation. Any new range activities should be sited to effectively utilize these existing areas, negating the need for additional impact areas.

\section{Erosion}

Erosion from impact areas should be kept at a minimum to control offsite movement of contaminated sediments. Filter strips and other erosion control structures placed on the borders of impact areas are imperative in controlling sediments. The most important management consideration for impact areas is to keep runoff from entering nearby surface waters.

\section{Dust Control}

If substantial dust is generated from impact areas, windbreaks should be maintained around the impact area to reduce dust movement as much as possible.

\section{Vegetation}

Maintaining vegetation around impact areas is very important for reducing sediment movement. Adequate vegetation in areas prone to overland flow of sediments from impact areas can significantly reduce the instances of contamination in nearby water bodies.

\section{Closure}

Closure of impact areas will most likely occur when an entire installation is closed. Unexploded ordnance will pose both a safety and environmental risk and will have to be located by specially trained personnel and detonated. Contaminated soils will have to be remediated either through excavation and removal or through on-site cleanup processes. 


\section{References}

32 CFR 651 (Title 32 Code of Federal Regulations Part 651), "Environmental Analysis of Army Actions (AR 200-2)," revised as of J uly 1, 2002.

33 CFR 320, "General Regulatory Policies," http:// www.usace.army.mil/inet/ functions/cw/ cecwo/ reg/33cfr320.htm

33 CFR, 330, "Nationwide Permit Program," http:// www.usace.army.mil/inet/ functions/cw/ cecwo/reg/33cfr320.htm

Army Regulation (AR) 200-1, Environmental Protection and Enhancement, Headquarters Department of the Army (HQDA), 21 February 1997.

AR 200-2, Environmental Effects of Army Actions, HQDA, 23J anuary 1989.

AR 200-3, Natural Resources - Land, Forest and Wildlife Management, Headquarters Department of the Army, 28 February 1995.

AR 200-4, Cultural Resources Management, HQDA, 1 October 1998.

Clean Air Act, as amended 42 USC 7401. Regulations promulgated under the CAA, 40 CFR 50-87.

Clean Water Act of 1977 (PL 95-217, 33 USC 1251).

Comprehensive Environmental Response, Compensation, and Liability Act of 1980 (PL 96-510, 42 USC 9601 et seq. (Chapter103)).

Copeland, Claudia, "Clean Water Act: A Summary of the Law", CRS Report for Congress, RL 30030, J anuary 20, 1999.

Department of the Army Pamphlet (DAPAM) 200-4, Cultural Resources Management, 1 October 1998.

Department of the Army, "Environmental Analysis of Army Actions” Final Rule, (AR 2002), 32 CFR 651, March 29, 2002.

Endangered Species Act of 1973. 16 USC 1531-1544, as amended, Public Law 93-205, approved December 28, 1973.

Environmental Protection Agency, Stormwater Rules: http://cfpub.epa.gov/npdes/regresult.cfm?program_id=6\&view=all\&type=1

Environmental Protection Agency Air Trends: http://www.epa.gov/airtrends/ Air Quality Planning and Standards: http://www.epa.gov/air/oaqps/cleanair.html Six Common Air Pollutants: http://www.epa.gov/air/urbanair/6poll.html

Executive Order (EO) 11990, Protection of Wetlands, May 24, 1977. 
National Environmental Policy Act of 1969 (PL90-190, 42 USC 4321-4347), J anuary 1, 1970. National Historic Preservation Act of 1966 as amended (32 CFR 800, 16 USC 470-470w).

Regulatory Program of the US Army Corps of Engineers, 33 CFR 320 - General Regulatory Policies, August 1997. http://wetlands.com/coe/coe320p2.htm

RETS [Remote Target System] Range Design Manual, CEHNC-1110-1-23, http://www.hnd.usace.army.mil/rtlp/index.aspx.

Rivers and Harbors Appropriation Act of 1899 (33 USC 403).

Sikes Act. 16 USC 670a-670o, as amended, Public Law 86-797, approved September 15, 1960. http:// www.epa.gov/ superfund/action/law/sara.htm

Superfund Amendment Reauthorization Act of 1986 (42 USC 9611 et seq (Chapter 103)

Superfund Amendments and Reauthorization Act (SARA). http:// www.epa.gov/ superfund/ action/law/ sara.htm

U.S. Army Corps of Engineers, Mobile District Regulatory Division, Regulatory Permit Program, November 1997. http://www.sam.usace.army.mil/rd/reg/permmob2.htm 


\section{Appendix A: Web Resources for Land Management and Erosion Control Laws and Regulations}

Sikes Act 1960

https://www.denix.osd.mil/denix/Public/ES-Programs/Conservation/Laws/sikes.html

National Historic Preservation Act of 1966, as amended

http://www.achp.gov/nhpa.html

National Environmental Policy Act (NEPA) 1969

http://ceq.eh.doe.gov/nepa/regs/nepa/nepaeqia.htm

Clean Water Act 1972

http://www.epa.gov/region5/water/cwa.htm

Endangered Species Act 1973

http://www.fws.gov/endangered/esa.html

Soil and Water Conservation Act 1977

http://ipl.unm.edu/cwl/fedbook/soilwate.html

American Indian Religious Freedom Act of 1978

http://www.cr.nps.gov/local-law/FHPL_IndianRelFreAct.pdf

Archaeological Resources Protection Act of 1979

http://www.cr.nps.gov/hps/laws/archprotect.htm

Comprehensive Environmental Response, Compensation, and Liability (CERCLA) 1980

http://www.access.gpo.gov/uscode/title42/chapter103_html

Clean Air Act 1990

http://www.epa.gov/oar/oaq_caa.html

National Pollutant Discharge Elimination System (NPDES)

http://cfpub.epa.gov/npdes

Native American Graves Protection and Repatriation Act (NAGPRA) 1990

http://www.cr.nps.gov/nagpra/

Native American Sacred Sites (EO 13007) 1996

http://www.cr.nps.gov/local-law/eo13007.htm 
Regulatory Program of the US Army Corps of Engineers, 33 CFR 320 General Regulatory Policies, August 1997

http://wetlands.com/coe/coe320p2.htm

U.S. Army Corps of Engineers, Mobile District Regulatory Division, Regulatory Permit Program, November 1997

http://www.sam.usace.army.mil/rd/reg/permmob2.htm

Army Regulation (AR) 200-1 Environmental Protection and Enhancement1997

http://www.usapa.army.mil/pdffiles/r200_1.pdf

Army Regulation (AR) 200-2 Environmental Effects of Army Actions 1988 http://www.usapa.army.mil/pdffiles/r200_2.pdf

Army Regulation (AR) 200-3 National Resources - Land, Forest, and Wildlife Management 1995

http://www.usapa.army.mil/pdffiles/r200_3.pdf

Army Regulation (AR) 200-4 Cultural Resources Management 1998

http://www.usapa.army.mil/pdffiles/r200_4.pdf

Superfund Amendments and Reauthorization Act (SARA).

http:// www.epa.gov/ superfund/ action/law/ sara.htm 


\section{Appendix B: Web Resources for Sustainable Ranges}

\section{Military Soil Erosion}

Erosion Potential Estimating Tool (EPET):

http:// danpatch.ecn.purdue.edu/ watergen/ erospot/

DENIX Erosion Modelling Tutorial

https://www.denix.osd.mil/denix/Public/Library/NCR/EMT/emt.html

Land Rehabilitation Potential Model (LRPM)

http:// pasture.ecn.purdue.edu/ watergen/lrpm

Environmentally Friendly Tank Trails

http://www.forester.net/ecm_0211_environmentally.html

CERL Sustainable Land Management Publications

http://www.cecer.army.mil/td/tips/browse/publications.cfm

Evaluation of Technologies for Addressing Factors Related to Soil Erosion on DoD Lands

http://owww.cecer.army.mil/techreports/pri\%5Fsoil/Pri\%5Fsoil.lln.post.PDF

USACE Public Works Technical Bulletins

http://www.hnd.usace.army.mil/techinfo/CPW/pwtb.htm

PWTB 200-3-29 Sources of Plant Materials for Land Rehabilitation, $05 / 06 / 20$

PWTB 200-3-30 Current Technologies for Erosion Control on Army Training Lands, 04/ 11/ 02

PWTB 200-3-32 Sources for Land Rehabilitation and Maintenance Equipment, 05/ 06/30

PWTB 200-3-33 Regional Cost Estimates for Rehabilitation and Maintenance Practices on Army Training Lands, 05/ 06/ 01

Prevention of Lead Migration and Erosion from Small Arms Ranges:

http://aec.army.mil/usaec/technology/leadmigration.pdf

\section{Revegetation}

VegSpec

http://vegspec.nrcs.usda.gov/vegSpec/index.jsp 
USDA Plants Database

http://plants.usda.gov/

CRREL Arid Land Grass Breeding Program

http://www.crrel.usace.army.mil/es/research/breeding.htm

USGS Recovery of Perennial Vegetation in Military Target Sites in the Eastern Mojave Desert, Arizona

http://geopubs.wr.usgs.gov/open-file/of00-355/of00-355.pdf

Nevada Measures to Prevent the Spread of Noxious and Invasive Weeds During Construction Activities

http://www.weedcenter.org/prevention/nv_prev_fact_sheet1.pdf

Native Plant Revegetation Guide for Colorado

http://parks.state.co.us/cnap/Revegetation_Guide/Reveg_index.html

A Guide to Restoring a Native Plant Community

http://faculty.washington.edu/clh/whitepapers/nativeplants.pdf

New York State Revegetation Procedures Manual

http://www.dec.state.ny.us/website/dmn/mines/reveg1.pdf

\section{Streambank Stabiliztation}

Pictures and Descriptions of Numerous Streambank Protection Practices http://www.tostreams.org/index.htm\#topics

Stream Restoration: Grade Control Practices

http://www.stormwatercenter.net/Assorted\%20Fact\%20Sheets/Restoration/grade_control.htm

Use of Riprap in Soil Bioengineering Streambank Protection

http://www.sotir.com/pubs/publist/riprap/riprap.html

Vegetated Gabions Offer Habitat Complexity for Fishery Streams http://www.forester.net/ec 0101 biotech.html

Best Management Practices for Wetlands within Colorado State Parks http://parks.state.co.us/cnap/Wetlands_BMP/6\%20-\%20Streams\%20and\%20Banks.pdf

Hawaii Coastal Erosion Management Plan

http://www.state.hi.us/dlnr/occl/files/coemap.pdf

Maryland Waterway Construction Guidelines

http://www.mde.state.md.us/assets/document/wetlandswaterways/intro.pdf

Mississippi Stream System Protection, Restoration, and Reestablishment http://www.abe.msstate.edu/csd/NRCS-BMPs/stream.html

Washington State Department of Transportation Standard Plans

http://www.wsdot.wa.gov/EESC/Design/designstandards/HTM/D6.htm 


\section{Erosion Control}

NRCS Conservation Engineering Tools and Documents (National Engineering Manual, National Engineering Handbook, Engineering Field Handbook)

http://www.info.usda.gov/CED/

Geosynthetically Reinforced Vegetation vs. Riprap

http://www.nagreen.com/resources/literature/2cases.pdf

Riprap

http://www.state.tn.us/environment/wpc/sed_ero_controlhandbook/rr.pdf

Mulch, Erosion Control

http://www.agfiber.org/mulch.html

Soil Loss

http://pasture.ecn.purdue.edu/ engelb/agen526/erosiondocs/erosionamc.html

Sediment Containment Measures

http://www.forester.net/ec 0005 holding.html

Chemical Soil Stabilization

http://www.forester.net/ecm_0301_chemical.html

Soil Erosion Control: Mulches, Blankets and Mats

http://www.metrocouncil.org/environment/Watershed/bmp/CH3_RPPSoilMulch.pdf

EPA Stormwater BMPs

http://cfpub.epa.gov/npdes/stormwater/menuofbmps/site_19.cfm

Runoff Management and Erosion Control

http://www.unu.edu/unupress/unupbooks/uu27se/uu27se09.htm

Soil Bioengineering Measures for Hill and Slope Stabilization Works with Plants

http://www.fao.org/docrep/x0622e/x0622e0s.htm

Alabama Handbook for Erosion Control, Sediment Control and Stormwater Management on Construction Sites and Urban Areas

http://swcc.state.al.us/pdf/ASWCC\%20June\%202003\%20Alabama\%20Handbook\%20Constructio n\%20E\&S\%20Control.pdf

California Stormwater Quality Association Construction Handbook http://www.cabmphandbooks.com/Construction.asp

Florida Stormwater, Erosion and, Sedimentation Control Inspector's Manual

http://www.dep.state.fl.us/water/nonpoint/ero_man.htm 
Georgia Stormwater Management Manual http://www.georgiastormwater.com/

Indiana Drainage Handbook http://www.in.gov/dnr/water/surface_water/DrainageHandbook/load.html

Kentucky Erosion and Sediment Control Field Guide http://www.tetratech-ffx.com/wstraining/pdf/esc guide.pdf

Maine Erosion and Sediment Control BMPs http://www.state.me.us/dep/blwq/docstand/escbmps/

Maryland Specifications for Soil Erosion and Sediment Control http://www.mde.state.md.us/Programs/WaterPrograms/SedimentandStormwater/erosionsedimentc ontrol/standards.asp

Michigan Department of Environmental Quality Soil Erosion and Sedimentation Control http://www.michigan.gov/deg/0,1607,7-135-3311_4113-81197--00.html

Minnesota Erosion Control Handbook for Local Roads http://www.lrrb.gen.mn.us/PDF/200308.pdf

Minnesota Protecting Water Quality in Urban Areas- A Manual http://www.pca.state.mn.us/water/pubs/sw-bmpmanual.html

Mississippi Water Related BMPs in the Landscape http://abe.msstate.edu/csd/NRCS-BMPs/contents.html

Missouri Controlling Runoff and Erosion at Urban Construction Sites http://muextension.missouri.edu/xplor/agguides/agengin/g01509.htm

Montana Erosion and Sediment Control Best Management Practices http://www.mdt.mt.gov/research/projects/env/erosion.shtml

New Hampshire Best Management Practices for Erosion Control during Trail Maintenance and Consrtuction http://www.nhtrails.org/Trailspages/BMPmanual2004.pdf

New Hampshire Best Management Practices to Control Nonpoint Source Pollution

http://www.des.state.nh.us/wmb/was/docs/2004_npsBMP.pdf

New Hampshire Innovative Stormwater Treatment Technologies Best Management Practices Manual http://www.des.state.nh.us/wmb/was/manual/

North Dakota Soil and Water Links

http://www.ag.ndsu.nodak.edu/abeng/links/Soil\%20Erosion

Oklahoma Using Vegetation for Erosion Control on Construction Sites http://osuextra.okstate.edu/pdfs/F-1514web.pdf 
Tennessee Erosion and Sediment Control Handbook http://www.tennessee.gov/environment/wpc/sed_ero_controlhandbook/

Texas Stormwater Management Guidelines for Construction Activities Manual

http://www.dot.state.tx.us/env/nrmstormwatermanual.htm

Vermont Handbook for Erosion Prevention and Sediment Control

http://www.anr.state.vt.us/dec/waterq/stormwater/htm/sw_erosionhandbk.htm

\section{Virginia Erosion and Sediment Control Handbook}

http://www.dcr.state.va.us/sw/e\&s-ftp.htm

West Virginia Best Management Practices for Controlling Soil Erosion and Sedimentation

http://www.wvforestry.com/\%28F\%29BMPs.pdf 


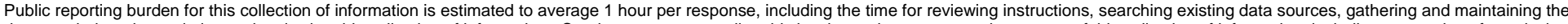

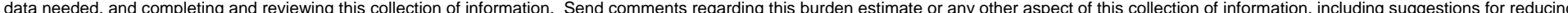

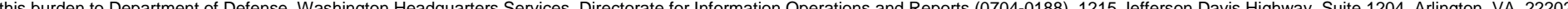

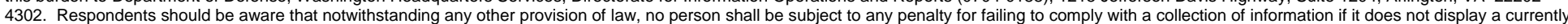
4302. Respondents should be aware that notwithstanding any other provision of law, no person shat
valid OMB control number. PLEASE DO NOT RETURN YOUR FORM TO THE ABOVE ADDRESS.

\begin{tabular}{l|lc}
\hline $\begin{array}{l}\text { 1. REPORT DATE (DD-MM-YYYY) } \\
12-2006\end{array}$ & 2. REPORT TYPE & Final \\
\hline 4. TITLE AND SUBTITLE & &
\end{tabular}

Guidance for Mitigating Environmental Concerns During Range Siting

3. DATES COVERED (From - To)

5a. CONTRACT NUMBER

5b. GRANT NUMBER

5c. PROGRAM ELEMENT NUMBER

6. AUTHOR(S)

Ryan Busby, Manroop Chawla, Mike Denight, Dick Gebhart, Heidi Howard, Tony Palazzo, and Niels Svendsen

5d. PROJECT NUMBER

5e. TASK NUMBER

5f. WORK UNIT NUMBER

8. PERFORMING ORGANIZATION REPORT NUMBER

7. PERFORMING ORGANIZATION NAME(S) AND ADDRESS(ES)
U.S. Army Engineer Research and Development Center (ERDC)

ERDC TR-06-16

PO Box 9005

Champaign, IL 61826-9005

9. SPONSORING I MONITORING AGENCY NAME(S) AND ADDRESS(ES)

HQ USACE / Office of the Director of Environmental Programs

C/O Humphreys Engineering Center

7701 Telegraph Road

Alexandria, VA 22315-3860

10. SPONSOR/MONITOR'S ACRONYM(S)

DAIM-ED-N

11. SPONSOR/MONITOR'S REPORT NUMBER(S)

12. DISTRIBUTION / AVAILABILITY STATEMENT

Approved for public release; distribution is unlimited.

13. SUPPLEMENTARY NOTES

Copies are available from the National Technical Information Service, 5285 Port Royal Road, Springfield, VA 22161.

\section{ABSTRACT}

The effective training of soldiers, leaders, and units is vital to ensure the readiness of the U.S. Army to fight and win decisively in combat. Training must provide the opportunity to practice individual and battle-focused tasks and missions in a setting where conditions are realistic and challenging. To facilitate this, the Army developed and continues to improve its training infrastructure, including combined arms training centers and an array of training areas, ranges, and target systems designed to increase individual skills and unit tactical and technical proficiency in sophisticated weapons systems and equipment.

Three key dynamics have evolved in recent years and are adversely affecting the Army's ability to continue to maintain its training mission: (1) a significant growth in environmental regulations to which installations must adhere, (2) many installations are becoming surrounded by population centers and are experiencing closer public scrutiny of activities that occur on installations, (3) transformation of the Army to the Objective Force.

This report provides information encompassing the major environmental factors that influence the planning and siting, design and construction, and operation and maintenance of the range elements most commonly found on training ranges and that possess the highest potential for environmental degradation.

\section{SUBJECT TERMS}

range management

environmental management

16. SECURITY CLASSIFICATION OF:

a. REPORT

Unclassified b. ABSTRACT

Unclassified training lands

land use planning c. THIS PAGE

Unclassified

\begin{tabular}{|c|c|}
\multirow{2}{*}{$\begin{array}{c}\text { 17. LIMITATION } \\
\text { OF ABSTRACT }\end{array}$} & $\begin{array}{c}\text { 18. NUMBER } \\
\text { OF PAGES }\end{array}$ \\
SAR & 89 \\
\end{tabular}

19a. NAME OF RESPONSIBLE PERSON Ryan Busby

19b. TELEPHONE NUMBER

(include area code)

(217) 352-6511, ext 7296 